Article

\title{
The Contribution of Ecosystem Services in Developing Effective and Sustainable Management Practices in Marine Protected Areas. The Case Study of "Isola dell'Asinara"
}

\author{
Maddalena Floris ${ }^{1}$, Vittorio Gazale ${ }^{2}$, Federica Isola ${ }^{1}$, Francesca Leccis ${ }^{1, *}$, Salvatore Pinna ${ }^{1}$ \\ and Cheti Pira ${ }^{1}$ \\ 1 Department of Civil and Environmental Engineering and Architecture, University of Cagliari, 09123 Cagliari, \\ Italy; maddalenafloris@gmail.com (M.F.); federica.isola@unica.it (F.I.); pinnasalvador@gmail.com (S.P.); \\ ing.cheti.pira@gmail.com (C.P.) \\ 2 "Isola dell'Asinara" Marine Protected Area, 07046 Porto Torres, Italy; gazale@asinara.org \\ * Correspondence: francescaleccis@gmail.com; Tel.: +39-347-356-6551
}

Received: 29 December 2019; Accepted: 31 January 2020; Published: 4 February 2020

\begin{abstract}
Ecosystem Services (ESs) are assuming a constantly increasing importance in management practices due to their key role in ensuring a sustainable future to fauna and flora on Earth. In addition, ES degradation and quality loss jeopardize current human activities. For this reason, it is essential to develop methodologies and practices able to efficiently assess environmental and socio-economic impacts in terms of ES deterioration, especially within protected areas. Norms and regulations have to be able to identify habitat and species categories to be preserved, and to determine the cost of their destruction and decline, according to a holistic vision, which includes social and economic impacts, besides the environmental ones. The paper illustrates the case study of the "Isola dell'Asinara" Marine Protected Area (MPA) in Sardinia, where an experimental methodology was developed with the aim to draw new regulations that integrate conservation measures of Natura 2000 sites included in its territory, provisions determined by the integrated coastal zone management (ICZM) protocol and the Standardized Actions for Effective Management of MPAs (ISEA) project. Subsequently, in order to assess the status of ESs and impacts on ESs located within the MPA territory, an ecosystem-based approach was implemented and applied to the actions defined for the new regulation proposal. Results show that regulations are in this way valuably enriched by environmental aspects of the MPA that would otherwise be overlooked.
\end{abstract}

Keywords: ecosystem services; millennium ecosystem assessment; marine protected areas; Natura 2000 network; integrated coastal zone management; standardized actions for effective management of marine protected areas; sustainable management; agenda 2030

\section{Introduction}

Commitment to biodiversity preservation has been increasing dramatically since the Convention on Biological Diversity in 1992. Thanks to international cooperation and stronger awareness of the close relationship between human needs and ESs, attention to ES preservation has grown exponentially over the years. Indeed, a constantly increasing number of scientific studies underline the fundamental role of marine and coastal ecosystems in providing important social and economic advantages [1-4], including food provisioning, nutrient cycling, biodiversity, climate regulation, cultural values, recreation and amenities [5] and the growing human dependence on marine ecosystems and their services [6]. 
However, overexploitation and mismanagement of marine and coastal resources, habitat destruction and water pollution jeopardize the wealth of ecosystems [7] and, consequently, the services they provide [2], thus threatening the well-being of local communities and of the global community as a whole in developing and industrial countries [8]. Nowadays, many coastal areas have been shown to be vulnerable due to ocean warming, sea level rise, flooding, storm surges, beach erosion, changes in ocean freshwater balance [9], overfishing, tourism and pollution [10,11]. Therefore, appropriate marine and coastal area management and governance are essential to limit environmental and ecosystem damages caused by human activities, to protect biodiversity [12-15] and to improve ecosystem resilience [2] and ecosystem services supply [16]. Scientific research shows that Ecosystem Services (ESs) have to be included in planning discourses [17], but this is still little done in practice [18]. Therefore, following the suggestions of the Strategic Plan for Biodiversity 2011-2020 and the related Aichi Targets, it is necessary to add a new conservation paradigm that integrates ESs in protected areas' planning rules in addition to the existing sets of biodiversity conservation measures [19]. The Strategic Plan for Biodiversity 2011-2020 was adopted in 2010 by the parties to the Convention on Biological Diversity, which has been ratified by 196 countries. Since the contracting countries are committed to the achievement of a number of targets by 2020, in 2011 the EU adopted the EU Biodiversity Strategy, which sets out six targets and 20 actions to halt the loss of biodiversity and ecosystem services in the EU by 2020. Among the objectives set by the strategy, this study focuses on those related to the preservation and protection of habitat, species and ESs located in Marine Protected Areas (MPAs) and Natura 2000 sites. In particular, regulation and planning aspects related to ESs are examined in the light of EU recommendations and communications in order to define research objectives and actions.

Marine Protected Areas (MPA) are globally recognized tools for managing marine ecosystems, specifically designed to safeguard biodiversity, to preserve marine ecosystem health, to maintain the supply of ESs [20], to prevent habitat loss [21] and to sustainably regulate human activities that affect the marine environment [22]. The aim is to reverse ecosystem and biodiversity loss, while sustaining local economy relying on sea and coastal resources [23]. The International Union for Conservation of Nature (IUCN) underlines that deep knowledge of the area is necessary in order to define ecological boundaries of the MPA and to set its objectives. It also calls attention to the vital support of the public and to established techniques for surveillance and monitoring of compliance with the provisions of the regulations. It plays an essential role in advocating the expansion of the MPA network through reliable science and by engaging with local stakeholders. In Europe, the State of the Environment Report (SOER) identifies three types of MPAs: Marine Natura 2000 sites, marine protected areas designed in the framework of regional marine agreements and the single national marine protected areas [24]. These three typologies of protected areas can overlap, that is, a specific zone can be disciplined according to more than one regulatory regime [25]. In Italy, MPAs are established through a ministerial order under the laws no. 979/1982 and no. 394/1991 and normally include three zones characterized by different levels of protection; namely, zone A, the "integral reserve", which is a no entry and no take zone; zone B, the "general reserve", which surrounds zone A where human activities and resource exploitation are severely restricted; and zone C, the "partial reserve", where human activities and resource exploitation are generally allowed but regulated [26]. It might occur that other regulatory regimes operate within the boundaries of an MPA, such as Natura 2000 network conservation measures for Special Protection Areas (SPAs), Special Areas of Conservation (SACs) and Sites of Community Importance (SCIs), the provisions determined by the integrated coastal zone management (ICZM) and by the Standardized Actions for Effective Management of MPAs (ISEA). SCIs, identified by European countries according to article 2 of European Directive 92/43/EEC on the conservation of natural habitats and of wild fauna and flora, subsequently labelled SACs, contribute towards ensuring bio-diversity through the conservation of natural habitats and of wild fauna and flora. SPAs, identified by European countries according to article 1 of European Directive 79/409/EEC on the conservation of wild birds, contribute to the conservation of all species of naturally occurring birds in the wild state in the European territory. In this way, fragmentation, spatial isolation and 
functional independence of protected areas often prevent a coordinated and integrated management of local activities, which might even present conflicts and contrasts that need to be handled. For example, the coexistence of tourist, commercial and fishery activities need multidisciplinary and integrated public policies [27]. In addition, managing protected areas as isolated reserves—without integrating them into wider spatial strategies-exposes them to the consequences of habitat alteration and destruction, pollution and overfishing that might occur outside their boundaries [28]. For these reasons, an integrated management tool able to adequately harmonize sector-specific policies according to a holistic vision of the territory that goes beyond fragmentation and sectoral policies is clearly crucial $[29,30]$. Researchers agree that its objectives must be clearly defined and compatible with one another [31-38] so that they need to be researched empirically through negotiation with stakeholders, balancing ecological concerns, economic interests, social issues and political power [39].

With the aim of developing the growth potential of marine and maritime economic activities in a sustainable way, the European Commission identified nine ongoing initiatives in the European Union, including the one on maritime spatial planning and integrated coastal zone management introduced by Directive 2014/89/EU and the one on the ecosystem-based approach introduced by the Marine Strategy Framework Directive (2008/56/EC) [40].

On the one hand, Directive 2014/89/EU defines maritime spatial planning as a cross-cutting policy tool enabling the application of a coordinated, integrated and trans-boundary ecosystem-based approach, which promotes smart, sustainable and inclusive growth and ensures sustainable use of marine and coastal resources [41]. On the other hand, Directive 2008/56/EC recommends ecosystem-based approaches for marine strategies, so that pressure of human activities does not compromise the capacity of marine ecosystems to respond to human-induced changes and the sustainable use of marine goods and services is ensured to present and future generations [42]. In Italy, according to article 2 subsection 3 and article 3 subsection 4 of the Decree of the Ministry of Environment, Land and Sea Protection (in Italian: Ministero dell'Ambiente e della Tutela del Territorio e del Mare, MATTM) published on 17th October 2007, the management of Natura 2000 sites located within the boundaries of an MPA is in charge of the MPA managing authority. Therefore, the MATTM demanded the integration of Natura 2000 conservation measures into MPA regulations in order to efficiently manage the area.

\section{The Case Study}

Among the tools identified by the European Union to promote trans-boundary cooperation there is the Interreg Maritime Italy-France Programme, which financed 87 projects [43] including the GIREPAM project (Integrated Management of Ecological Networks through Parks and Marine Areas; in Italian: Gestione Integrata delle Reti Ecologiche attraverso i Parchi e le Aree Marine), which involves 16 partners located in five Italian and French regions (Sardinia, Corsica, Provence-Alps-Côte d'Azur, Liguria and Tuscany) and pursues the following three objectives:

1. To improve conservation and promotion of marine and costal zones and to direct public accessibility to natural sites.

2. To improve the efficiency of planning and public governance of marine and coastal areas in the area of cooperation.

3. To raise awareness on the economic value of the natural capital and to promote green and blue growth [44].

The research group of the Department of Civil and Environmental Engineering and Architecture (DICAAR) of the University of Cagliari worked on the second objective by outlining an Experimental Procedure (in Italian: Protocollo Sperimentale, PS) aiming at formulating appropriate regulations for the management and control of the Marine Protected Areas (MPAs) named "Tavolara-Punta Coda Cavallo" and "Isola dell'Asinara" located in north-eastern and north-western Sardinia, respectively, as shown in Figures 1 and 2. 


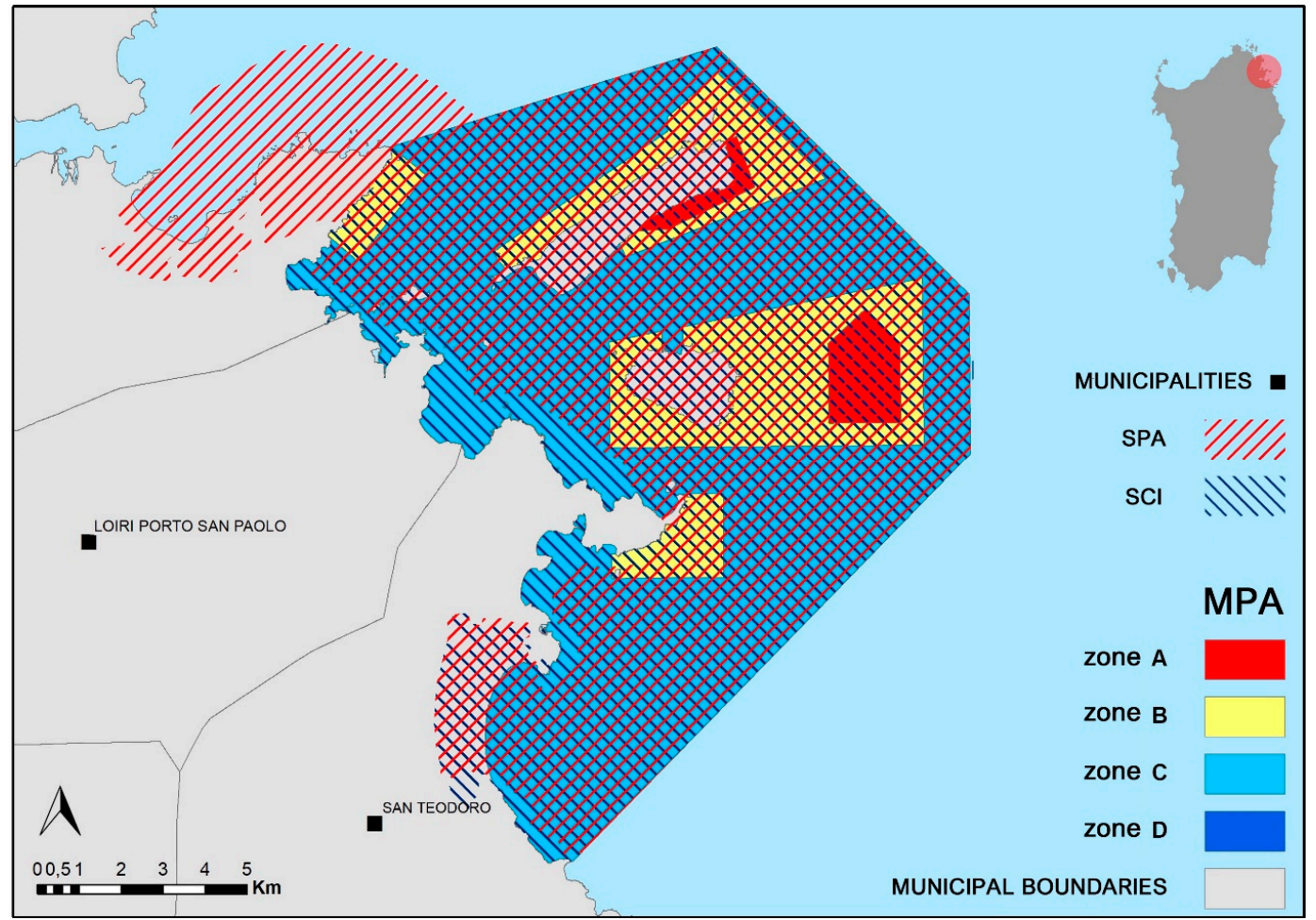

Figure 1. The territory of "Tavolara-Punta Coda Cavallo" Marine Protected Area (MPA) and of the Natura 2000 sites that overlap with it. Source: Authors' elaboration.

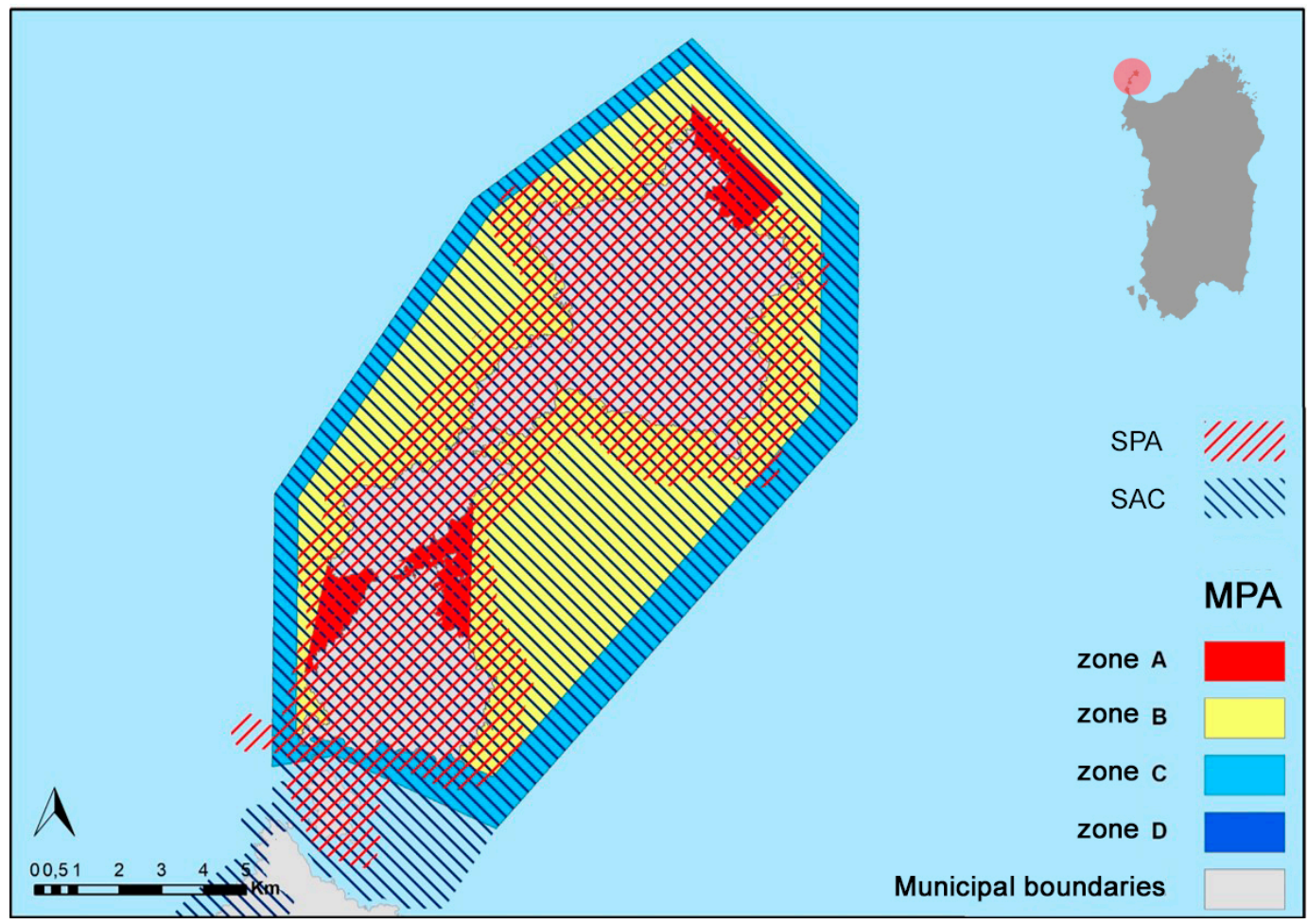

Figure 2. The territory of "Isola dell'Asinara" MPA and of the Natura 2000 sites that overlap with it.Source: Authors' elaboration.

Figures 1 and 2 show that SPAs, SACs and SCIs are located within the boundaries of the MPAs of "Tavolara-Punta Coda Cavallo" and "Isola dell'Asinara". Consequently, conservation measures 
identified by the Natura 2000 network for SPAs, SACs and SCIs are in force in the MPAs. In addition, the ICZM protocol and the ISEA project are adopted by the MPAs; therefore, the provisions they determine are in force in the MPAs as well. The PS aims at integrating these legislative measures in a single document, coherently with a holistic territory vision able to ensure favorable conservation status of habitats, thus preserving biodiversity.

Within the framework of the study carried out by the DICAAR research group, following the provisions provided by the European Directives 2014/89/EU and 2008/56/EC mentioned above, this paper focuses on the definition of a pioneering methodology to define "ecosystemic objectives", in accordance with the Sustainable Development Goals (SDGs) of Agenda 2030, to enrich the traditional assessment for sustainability provided by the Strategic Environmental Assessment (SEA). In this way, ecological and socio-economic disciplines are integrated to provide decision-makers with a synthesis of complex information to inform strategies definition. The aim is to provide a scientific framework, which integrates ecosystem services in environmental assessment procedures, in order to guide managers and legislators in making sound decisions.

For the purpose of this paper, only data concerning the MPA of "Isola dell'Asinara" are considered. The MPA was established in 2002 by a decree of the MATTM and its current regulations were approved by the MATTM through the decree of the 30th of July 2009 [45]. Its area covers approximately $108 \mathrm{~km}^{2}$ in the sea and $79.64 \mathrm{~km}^{2}$ in the mainland entirely comprised within the boundaries of the Municipality of Porto Torres, in the Province of Sassari [46]. The MPA territory overlaps with the following Natura 2000 sites: The SPA "ITB010001 Isola Asinara", the SPA "ITB013011 Isola Piana di Porto Torres" and the SAC "ITB010082 Isola dell'Asinara", as shown in Figure 2 [47]. It is characterized by an extensive coverage of various high-quality assets of natural capital as shown in Figure 3.

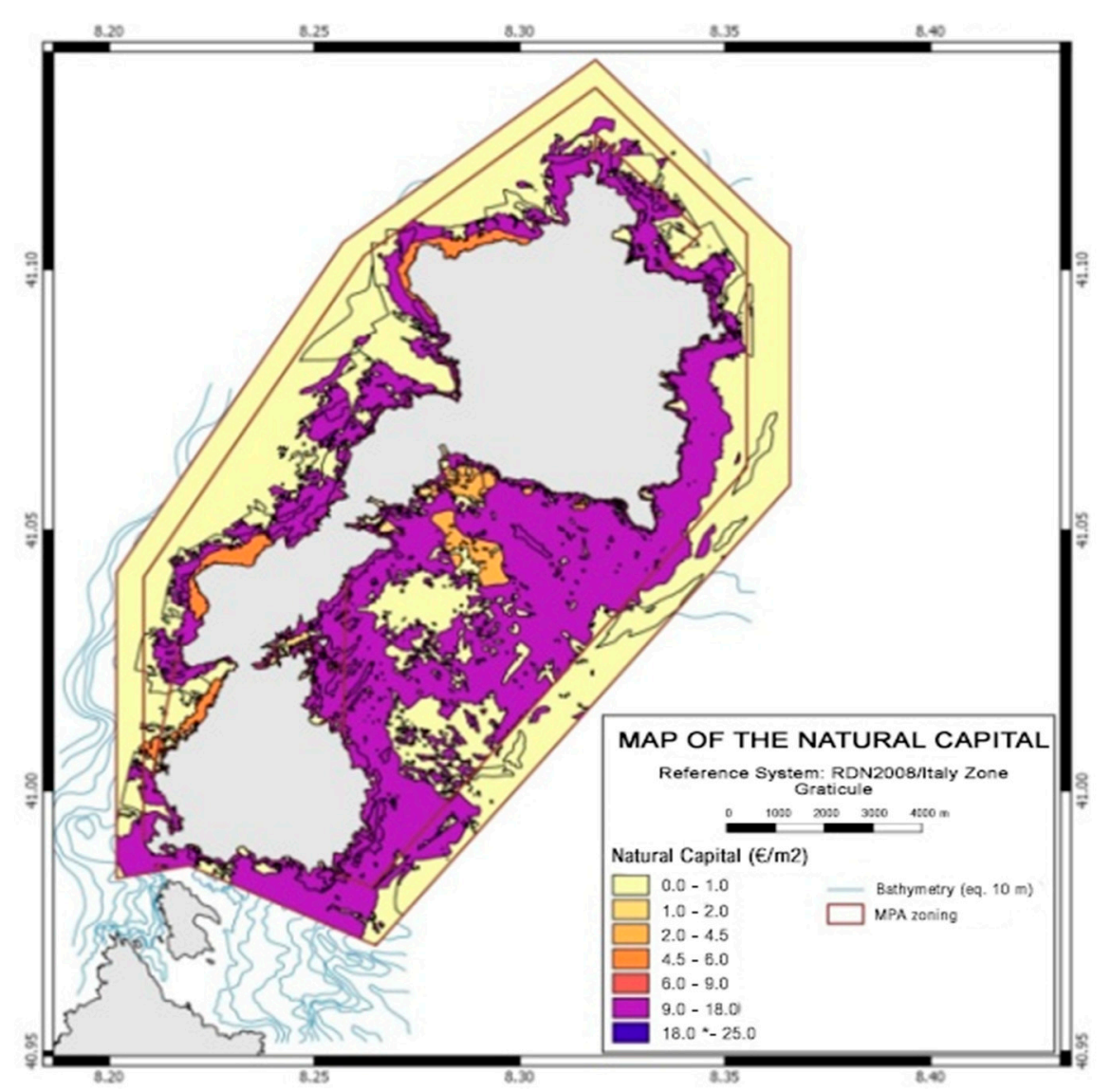

Figure 3. Map of the natural capital. Source: Povero et al., 2018 [48]. 


\section{Methodology}

The approach adopted for the definition of the new MPA regulation proposal is based on the outline of the PS. It draws inspiration from the Strategical Environmental Assessment (SEA), with particular reference to articles 1 and 6 of Directive 2001/42/CE, which concern decisional processes and public participation. In particular, the PS recalls the principle that the SEA is not a simple assessment of environmental impacts related to a decision, but it plays a strategic role in all the stages of the whole decisional process $[49,50]$. In this respect, the SEA is an effective political instrument for territorial governance, able to define strategical actions through the integration of diverse approaches and tools [49,51-55].

The PS applies these concepts with the aim of enhancing decisional processes and management practices. In particular, it promotes public participation in a holistic vision pointing at going beyond the fragmentation and sectorization that characterize the planning and management tools in force. It is structured into the sections illustrated in Figure 4.

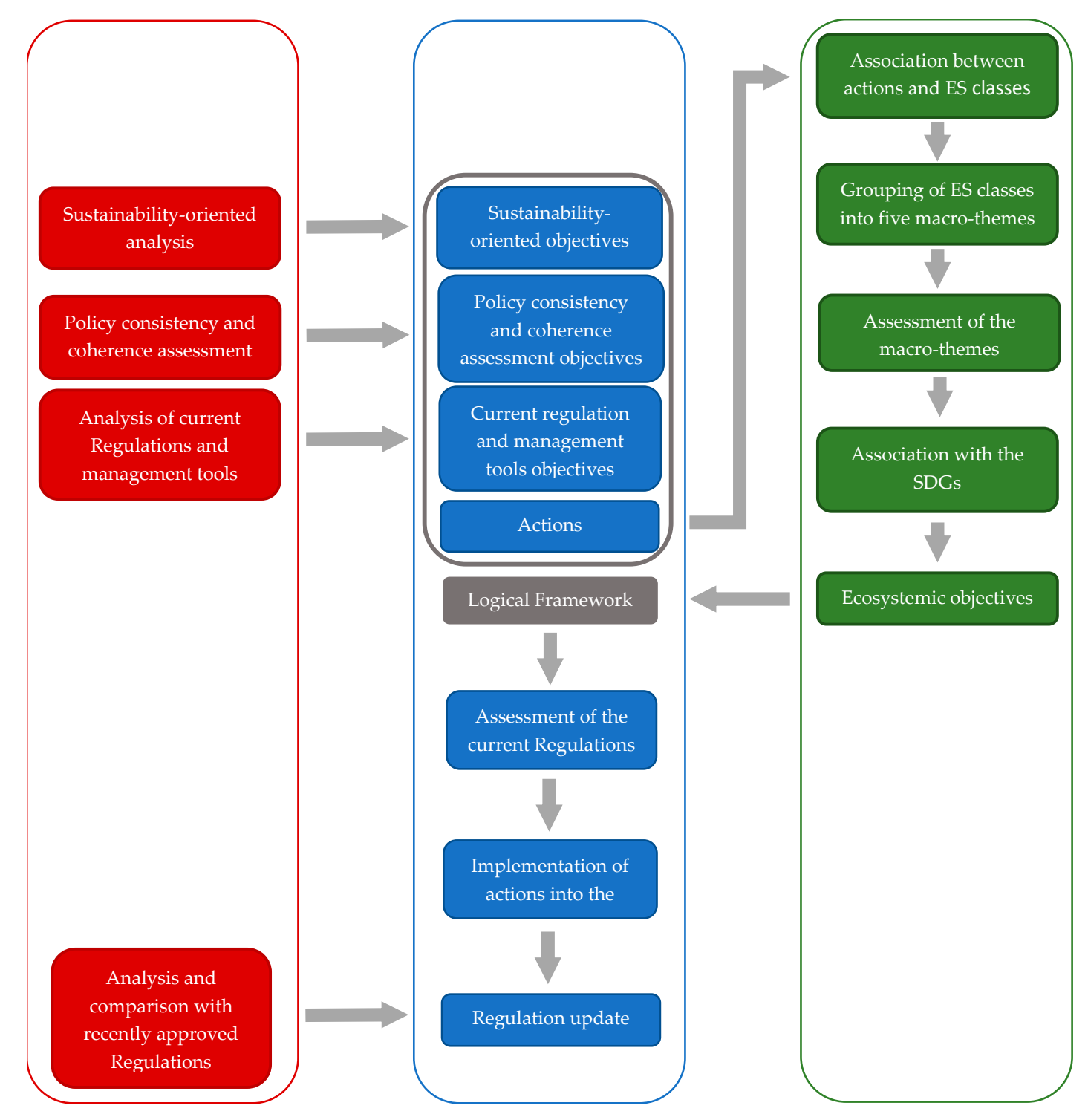

Figure 4. The Experimental Procedure (PS) scheme. Source: Authors' elaboration.

The core of the PS is constituted by the Logical Framework (LF), since it organizes all the objectives and actions identified in the previous sections, and connects them in a cascade relationship. The LF 
is organized according to a matrix structure, largely adopted in the programs promoted by the EU and other international entities. The LF is inspired to the so-called "programming by objectives", according to which the definition of the activities strictly follows the objective identification [56-58]. The LF structure ensures the identification of "conceptual connections between sustainability-oriented objectives related to the spatial contexts at stake and the operational planning actions concerning the integration of conservation measures related to" Natura 2000 sites into the new regulation proposal [59]. It is organized into four levels, which express the relationships among the various objectives drawn from the diverse protection instruments analyzed during the process of regulation elaboration (see Figure 4) and the actions defined to pursue the objectives selected for the prospective regulations.

The first level lists the sustainability-oriented objectives-formulated on the basis of the SWOT analysis-which depict the environmental status of the area through the analysis of each environmental component that characterizes the area [60]. The second level encompasses the objectives derived from the policy consistency and coherence assessment, which analyzes plans and programs in force at the regional, provincial and local level. The aim of this analysis is to identify the potential effects of plans and programs within the MPA territory and their interaction with the regulations. The third level enumerates specific objectives. They represent the regulation aims, as their codification is based on the contents of normative and management tools in force within the MPA. This section is the core of the PS, due to its importance within the process of upgrading the regulations, and its subsequent implementation.

The last level of the LF is the operative one, since it identifies the actions that address regulation objectives. In order to draw an efficient new regulation proposal, actions are formulated considering the planning and management tools in force (specific objectives) and the results of the SWOT analysis. These actions are then compared with the legislative instruments in force, which are in this way integrated in the new regulation proposal.

\section{The Construction of the Logical Framework}

As illustrated in Figure 4, the first level of the LF is constituted by the sustainability-oriented objectives. These objectives result from the analysis of various environmental and socio-economic aspects that describe the analyzed area. The environmental components are identified on the basis of the list provided by the guidelines issued by the Sardinian Region adequately adapted to the MPA studied [61]. In particular, the following ten "environmental components" are examined:
1. Air;
2. Water;
3. Waste treatment;
4. Soil and marine geo-morphology;
5. Flora, fauna and biodiversity;
6. Landscape;
7. Settlement layout and functions;
8. Tourism, recreation and outreach activities;
9. Fishing and other production activities;
10. Mobility and marine and terrestrial accessibility.

Characteristics of each component are reported in a summary sheet, whose scheme is illustrated in Table 1. The sheet contains the essential information assessing the status of natural resources and the pressures of anthropic and economic factors, which can be relevant in the phase of implementation of the regulations. Contextually, a SWOT analysis is conducted to analyze each environmental component, considering data drawn from the context analysis, in order to finally define a set of sustainability-oriented objectives. Subsequently, these objectives are better focused thanks to the ten sustainability criteria identified by the EC [48]. 
Table 1. Summary sheet for the analysis of the environmental components.

\begin{tabular}{|c|c|}
\hline \multicolumn{2}{|c|}{ Environmental Component $K$} \\
\hline \multirow{2}{*}{\multicolumn{2}{|c|}{$\begin{array}{l}\text { The introduction qualitatively describes the environmental component } \mathrm{K} \text { in the analyzed territorial context } \\
\text { (i.e., air). } \\
\text { The description is organized according to themes (i.e., air quality, meteorological conditions), which are in turn } \\
\text { articulated in specific aspects (i.e., source of pollution, temperature, annual precipitation, etc.). The latter } \\
\text { provide a quantitative analysis based on appropriate indicators. }\end{array}$}} \\
\hline & \\
\hline \multicolumn{2}{|c|}{ Theme $n$} \\
\hline \multicolumn{2}{|c|}{$\begin{array}{l}\text { This section provides a brief qualitative description of the theme } \mathrm{n} \text {, which refers to the environmental } \\
\text { component } \mathrm{K} \text {. }\end{array}$} \\
\hline \multicolumn{2}{|c|}{ Specific aspect $\mathrm{t}$} \\
\hline \multicolumn{2}{|c|}{$\begin{array}{l}\text { Brief description of the aspect through its distinguishing elements such as legislative and management tools, } \\
\text { operational tools, thematic maps, infrastructure, etc. }\end{array}$} \\
\hline \multicolumn{2}{|l|}{ Indicator 1 [unit] } \\
\hline$\ldots$ & \multirow[t]{2}{*}{ Notes } \\
\hline Indicator $\mathrm{n}$ [unit] & \\
\hline \multicolumn{2}{|c|}{$\begin{array}{c}\text { Source: .... } \\
\text { Year: ... }\end{array}$} \\
\hline \multicolumn{2}{|c|}{ SWOT Analysis } \\
\hline Strengths & Weaknesses \\
\hline$\ldots$ & $\cdots$ \\
\hline Opportunities & Threats \\
\hline$\ldots$ & $\cdots$ \\
\hline Sustainability-oriented Objectives & Environmental sustainability criteria \\
\hline Ps_Ob_SA_n ... & $\ldots$ \\
\hline
\end{tabular}

Table 2 shows the SWOT analysis conducted for the "air" component, in relation to the sustainability-oriented objective: "Increasing air quality by mitigating pollution impacts, in order to control negative effects caused by climate change". It highlights strengths, weaknesses, opportunities and threats related to the component "air". Subsequently the identified sustainability-oriented objective is compared to the appropriate environmental sustainability criteria, designated by the EC [42] (The ten sustainability criteria are the following: (i) Minimization of the use of non-renewable resources; (ii) use of renewable resources within limits of capacity for regeneration; (iii) environmentally sound use and management of hazardous/polluting substances and wastes; (iv) conservation and enhancement of the status of wildlife, habitats and landscapes; (v) maintenance and improvement of the quality of soils and water resources; (vi) maintenance and improvement of the quality of historic and cultural resources; (vi) maintenance and improvement of the local environmental quality; (viii) protection of the atmosphere (global warming); (ix) development of environmental awareness, education and training; (x) promotion of public participation in decisions involving sustainable development). In particular, the sustainability-oriented objective here identified is better focused by considering the environmental sustainability criteria numbers $\mathrm{i}$, ii, iii, vii and viii. 
Table 2. SWOT analysis.

\begin{tabular}{|c|c|}
\hline \multicolumn{2}{|c|}{ SWOT Analysis } \\
\hline Strengths & Weaknesses \\
\hline - Absence of air pollution sources within the MPA. & $\begin{array}{l}\text { - Absence of monitoring networks able to } \\
\text { promptly provide information within the } \\
\text { MPA territory. } \\
\text { - Potential air pollution within the MPA } \\
\text { boundaries, due to motor boats. }\end{array}$ \\
\hline Opportunities & Threats \\
\hline $\begin{array}{l}\text { - Favorable meteorological conditions during the } \\
\text { summer period, and mild weather during the winter. }\end{array}$ & $\begin{array}{l}\text { - Presence of pollution sources near the MPA, } \\
\text { namely the Porto Torres industrial area and Fiume } \\
\text { Santo power station. }\end{array}$ \\
\hline $\begin{array}{l}\text { Sustainability-oriented } \\
\text { Objective }\end{array}$ & Environmental sustainability criteria \\
\hline $\begin{array}{c}\text { - To enhance air quality by reducing the pollution } \\
\text { consequences in order to mitigate negative effects } \\
\text { caused by climate change. }\end{array}$ & i, ii, iii, vii, viii \\
\hline
\end{tabular}

The second level of the LF is represented by the policy consistency and coherence objectives.

The assessment of policy consistency and coherence considers all the plans and programs in force at any level in the Marine Protected Area by examining the economic, social and spatial aspects relevant to the analyzed context. All the objectives illustrated in each plan or program are analyzed, and those considered meaningful for the regulations are adopted, either identical to their original formulation or adequately rephrased in order to be specifically tailored to the context.

For example, the objectives identified in relation to the Regional Air Quality Plan are listed below:

- To pursue general environmental enhancement, in relation to other zones and types of polluting substances;

- to integrate environmental needs in sectorial policies (especially in the sectors of energy, industry and transportation) with the aim of ensuring sustainable socio-economic development;

- to increase citizen awareness in order to promote environmentally friendly behavior;

- to integrate authorizations and inspection and monitoring activities in order to best ensure the implementation of the planning and regulation actions.

The third level of the LF is constituted of the specific objectives drawn from the various regulatory regimes in force in the "Isola dell'Asinara" MPA, with the aim of grouping them into a single regulatory framework. In correspondence with each objective, one or more actions are identified in order to guarantee the implementation of the objectives of the new regulation proposal. Simultaneously, actions pursue the aim of eliminating — or at least reducing - pressures exerted on natural resources by anthropic factors. In Tables 3 and 4 excerpts of the LF referring to the "air" component are reported. 
Table 3. LF excerpt referring to the "air" component.

\begin{tabular}{|c|c|c|}
\hline $\begin{array}{l}\text { Sustainability-Oriented } \\
\text { Objectives }\end{array}$ & $\begin{array}{c}\text { Policy Consistency and Coherence } \\
\text { Objectives }\end{array}$ & Regulation Objectives (Specific Objectives) \\
\hline \multirow{13}{*}{$\begin{array}{l}\text { Ps_Ob_SA_1 } \\
\text { To enhance air quality by reducing } \\
\text { pollution consequences, in order } \\
\text { to mitigate the negative effects } \\
\text { caused by climate change. }\end{array}$} & \multirow{4}{*}{$\begin{array}{c}\text { Ps_Ob_CE_4 } \\
\text { To increase citizen awareness in order to } \\
\text { promote environmentally friendly behaviors. }\end{array}$} & $\begin{array}{l}\text { PS_Ob_REO_10 } \\
\text { To organize information, promotional, } \\
\text { awareness-raising and educational programs in } \\
\text { order to guarantee sustainable fruition of the area } \\
\text { and of its natural resources. }\end{array}$ \\
\hline & & $\begin{array}{l}\text { PS_Ob_REO_11 } \\
\text { To promote the development of economic, social, } \\
\text { cultural and tourist activities, which are } \\
\text { compatible with conservation needs. }\end{array}$ \\
\hline & & $\begin{array}{l}\text { PS_Ob_REO_12 } \\
\text { To promote programs and projects directed to the } \\
\text { enhancement of marine ecosystems. }\end{array}$ \\
\hline & & $\begin{array}{c}\text { PS_Ob_REO_16 } \\
\text { To ensure efficiency in the integrated } \\
\text { management of the MPAs. }\end{array}$ \\
\hline & \multirow{3}{*}{$\begin{array}{l}\text { Ps_Ob_CE_5 } \\
\text { To monitor natural phenomena and processes } \\
\text { in order to support authorization and control } \\
\text { procedures for a better implementation of the } \\
\text { regulation actions. }\end{array}$} & $\begin{array}{c}\text { PS_Ob_REO_18 } \\
\text { To efficiently organize surveillance and assistance } \\
\text { activities. }\end{array}$ \\
\hline & & $\begin{array}{l}\text { PS_Ob_REO_19 } \\
\text { To promote scientific investigation programs. }\end{array}$ \\
\hline & & $\begin{array}{c}\text { PS_Ob_REO_20 } \\
\begin{array}{c}\text { To monitor the state of conservation of habitats } \\
\text { and species. }\end{array}\end{array}$ \\
\hline & \multirow{3}{*}{$\begin{array}{l}\text { Ps_Ob_CE_11 } \\
\text { To integrate sustainable development policies, } \\
\text { in order to reduce and prevent climate change } \\
\text { and desertification impacts, by reducing the } \\
\text { emission of climate-changing gas. }\end{array}$} & $\begin{array}{l}\text { PS_Ob_REO_8 } \\
\text { To efficiently organize recreational boat activities, } \\
\text { mooring and docking, in compliance with the } \\
\text { rules in force in each zone of the MPA and with } \\
\text { the related Code of Conduct. }\end{array}$ \\
\hline & & $\begin{array}{l}\text { PS_Ob_REO_13 } \\
\text { To reduce the main anthropic pressure factors. }\end{array}$ \\
\hline & & $\begin{array}{c}\text { PS_Ob_REO_16 } \\
\text { To ensure efficiency in the integrated } \\
\text { management of the MPAs. }\end{array}$ \\
\hline & $\begin{array}{c}\text { Ps_Ob_CE_13 } \\
\text { To increase knowledge, applied research and } \\
\text { experimentation. }\end{array}$ & $\begin{array}{c}\text { PS_Ob_REO_19 } \\
\text { To promote scientific investigation programs. }\end{array}$ \\
\hline & \multirow[t]{2}{*}{$\begin{array}{l}\text { Ps_Ob_CE_16 } \\
\text { To reduce energy consumption, pollutant } \\
\text { emissions and their impacts on the MPA } \\
\text { territory, landscape and environmental value. }\end{array}$} & $\begin{array}{c}\text { PS_Ob_REO_8 } \\
\text { To efficiently organize recreational boat } \\
\text { navigation, mooring and docking, in compliance } \\
\text { with the rules in force in each zone of the MPA } \\
\text { and with the related code of conduct. }\end{array}$ \\
\hline & & $\begin{array}{l}\text { PS_Ob_REO_13 } \\
\text { To reduce the main anthropic pressure factors. }\end{array}$ \\
\hline
\end{tabular}

Table 4. LF excerpt referring to the "air" component.

\begin{tabular}{ccc}
\hline $\begin{array}{c}\text { Sustainability-Oriented } \\
\text { Objectives }\end{array}$ & $\begin{array}{c}\text { Regulation Objectives } \\
\text { (Specific Objectives) }\end{array}$ & Regulation Actions \\
\hline Ps_Ob_SA_1 & Ps_Ob_REO_11,Ps_Ob_REO_13 & $\begin{array}{c}\text { Act_REO_3 } \\
\text { Positioning of landing stages and buoys for the } \\
\text { mooring of recreational boats in proximity of the } \\
\text { Asinara island, in order to preserve Posidonia oceanica } \\
\text { habitats. }\end{array}$ \\
\cline { 2 - 3 } $\begin{array}{c}\text { To enhance air quality by reducing } \\
\text { pollution consequences, in order } \\
\text { to mitigate the negative effects } \\
\text { caused by climate change. }\end{array}$ & Ps_Ob_REO_11,Ps_Ob_REO_13 & $\begin{array}{c}\text { Act_REO_4 } \\
\text { Realization of artificial submerged barriers in order } \\
\text { to constrict illegal trawling and to protect Posidonia } \\
\text { oceanica meadows. }\end{array}$ \\
\hline
\end{tabular}


Table 4. Cont.

\begin{tabular}{|c|c|c|}
\hline $\begin{array}{l}\text { Sustainability-Oriented } \\
\text { Objectives }\end{array}$ & $\begin{array}{l}\text { Regulation Objectives } \\
\text { (Specific Objectives) }\end{array}$ & Regulation Actions \\
\hline & Ps_Ob_REO_18 & $\begin{array}{c}\text { Act_REO_7 } \\
\text { To adopt measures to facilitate the rescue of animals } \\
\text { in distress or disoriented. }\end{array}$ \\
\hline & Ps_Ob_REO_10 & $\begin{array}{c}\text { Act_REO_8 } \\
\text { To regulate photo shoots, filming and TV recordings. }\end{array}$ \\
\hline & $\begin{array}{l}\text { Ps_Ob_REO_8, Ps_Ob_REO_10, } \\
\text { Ps_Ob_REO_13 }\end{array}$ & $\begin{array}{l}\text { Act_REO_11 } \\
\text { To regulate activities allowed in each MPA zone. }\end{array}$ \\
\hline & Ps_Ob_REO_10, Ps_Ob_REO_13 & $\begin{array}{l}\text { Act_REO_12 } \\
\text { To organize the tourism fruition system within the } \\
\text { MPA. }\end{array}$ \\
\hline & Ps_Ob_REO_8 & $\begin{array}{l}\text { Act_REO_13 } \\
\text { To control and limit ship and boat speed, in order to } \\
\text { reduce underwater noise pollution and the risk of } \\
\text { collision with cetaceans and turtles. }\end{array}$ \\
\hline & Ps_Ob_REO_20 & $\begin{array}{c}\text { Act_REO_14 } \\
\text { To regulate monitoring activity. }\end{array}$ \\
\hline & Ps_Ob_REO_10,Ps_Ob_REO_13 & $\begin{array}{c}\text { Act_REO_18 } \\
\text { To design and create submarine paths. }\end{array}$ \\
\hline & Ps_Ob_REO_12 & $\begin{array}{c}\text { Act_REO_19 } \\
\text { To launch seabed cleaning campaigns. }\end{array}$ \\
\hline & Ps_Ob_REO_19 & $\begin{array}{l}\text { Act_REO_20 } \\
\text { To regulate technical and scientific research activity. }\end{array}$ \\
\hline & Ps_Ob_REO_13 & $\begin{array}{l}\text { Act_REO_21 } \\
\text { To regulate bathing and swimming. }\end{array}$ \\
\hline & Ps_Ob_REO_8 & $\begin{array}{c}\text { Act_REO_24 } \\
\text { To regulate recreational boat activities. }\end{array}$ \\
\hline & Ps_Ob_REO_8 & $\begin{array}{l}\text { Act_REO_25 } \\
\text { To regulate docking of recreational boats. }\end{array}$ \\
\hline & Ps_Ob_REO_8 & $\begin{array}{l}\text { Act_REO_26 } \\
\text { To regulate mooring of recreational boats. }\end{array}$ \\
\hline & Ps_Ob_REO_11 & $\begin{array}{c}\text { Act_REO_31 } \\
\text { To regulate chartering and leasing_even } \\
\text { temporary—of recreational boats. }\end{array}$ \\
\hline & Ps_Ob_REO_11, Ps_Ob_REO_13 & $\begin{array}{c}\text { Act_REO_33 } \\
\text { To define a set of indicators to asses carrying capacity } \\
\text { of the MPA during the summer. }\end{array}$ \\
\hline & Ps_Ob_REO_11 & $\begin{array}{c}\text { Act_REO_34 } \\
\text { To regulate authorizations for the development of } \\
\text { socio-economic, tourist, social and cultural activities } \\
\text { within the MPA. }\end{array}$ \\
\hline & Ps_Ob_REO_11 & $\begin{array}{c}\text { Act_REO_35 } \\
\text { To adopt measures to preserve and protect the } \\
\text { archaeologic, historic and cultural submarine } \\
\text { heritage. }\end{array}$ \\
\hline & Ps_Ob_REO_8 & $\begin{array}{c}\text { Act_REO_41 } \\
\text { To systematize the mooring infrastructure. }\end{array}$ \\
\hline & Ps_Ob_REO_20 & $\begin{array}{c}\text { Act_REO_42 } \\
\text { To launch monitoring campaigns to collect data on } \\
\text { air quality. }\end{array}$ \\
\hline
\end{tabular}

Once the LF is completely filled, actions are compared with the regulations in force in order to evaluate their mutual coherence. In the event that the regulations in force in the MPAs do not include — or only partially include - a particular action, the regulations are updated either by adding new articles and subsections, or by modifying the existing ones. In order to best pursue this upgrading, regulations in force are also compared with regulations recently approved in other Italian MPAs, which are considered as best practices from which inspiration is taken. Table 5 shows the methodological model adopted to revise the regulations in force and is based on a double level of assessment. 
Table 5. Methodology adopted to revise the regulations in force.

\begin{tabular}{|c|c|c|c|c|c|c|}
\hline \multicolumn{7}{|c|}{ Title } \\
\hline $\begin{array}{l}\text { Regulations in } \\
\text { Force }\end{array}$ & \multirow{2}{*}{\multicolumn{3}{|c|}{$\begin{array}{l}\text { First Assessment Level: } \\
\text { Comparison between Actions and Articles } \\
\text { of Regulations in Force }\end{array}$}} & \multirow{2}{*}{\multicolumn{2}{|c|}{$\begin{array}{l}\text { Second Assessment Level: } \\
\text { Comparison with Recently } \\
\text { Approved Regulations }\end{array}$}} & $\begin{array}{l}\text { Regulation } \\
\text { Update }\end{array}$ \\
\hline $\begin{array}{l}\text { Article from } \\
\text { Regulations in } \\
\text { Force }\end{array}$ & & & & & & $\begin{array}{l}\text { Article of the } \\
\text { Updated } \\
\text { Regulations }\end{array}$ \\
\hline Subsection & Action & $\begin{array}{l}\text { Article/action } \\
\text { assessment }\end{array}$ & $\begin{array}{l}\text { Remarks } \\
\text { about the } \\
\text { article/action } \\
\text { assessment }\end{array}$ & $\begin{array}{l}\text { Recent } \\
\text { approved } \\
\text { regulations }\end{array}$ & $\begin{array}{l}\text { Remarks about the } \\
\text { comparison with } \\
\text { recent approved } \\
\text { regulations }\end{array}$ & $\begin{array}{c}\text { New subsection } \\
\text { proposal }\end{array}$ \\
\hline
\end{tabular}

As a result of this double comparison, the new regulation proposal includes the aspects that characterize the sectorial norms that coexist in the area and those drawn from the regulations recently approved in other Italian MPAs. This integration aims at reinforcing biodiversity and environmental conservation, while guaranteeing efficient management of all the socio-economic activities in the area.

\section{Definition of the PS Actions}

While the objectives constitute the structural dimension of the PS, the actions, in turn, embody the operational aspect, by providing detailed indications and restrictions for the organization and management of the MPA. Following the criteria adopted for the identification of the regulation objectives, actions are codified considering the current restrictions imposed by the legislation in force. These are the MPA establishment decree, the regulations, the management plans of the Natura 2000 sites, and the provisions of the ICZM protocol and of the ISEA project. In addition, the results of the environmental analysis_-in particular, the SWOT analysis_-for each environmental component have been considered. In this way, actions result strictly linked to the regulation objectives and well connected to the strategic themes raised during their definition.

Once defined, actions were grouped by the categories that characterize the regulations in force as illustrated below:

- Dispositions and regulatory norms;

- monitoring;

- promotional, awareness-raising, information and educational programs;

- $\quad$ security and surveillance;

- institutional coordination.

Attention has been focused on the dispositions and regulatory norms showing a strong link between the sustainable use of natural resources and the protection of marine habitats and species.

Table 6 reports the action set defined.

Table 6. Regulation actions. Source: PS of "Isola dell'Asinara" MPA.

\begin{tabular}{cl}
\hline Code & Action \\
\hline Action category: DISPOSITIONS AND REGULATORY NORMS \\
\hline ACT_Reg_1 & To adopt protection and conservation measures for habitats and species. \\
\hline ACT_Reg_2 & To regulate the management of stranded Posidonia oceanica. \\
\hline ACT_Reg_3 & $\begin{array}{l}\text { Positioning of landing stages of buoys for the mooring of recreational } \\
\text { boats in proximity of the Asinara island in order to preserve Posidonia } \\
\text { oceanica habitats. }\end{array}$ \\
\hline ACT_Reg_4 & $\begin{array}{l}\text { Realization of artificial submerged barriers in order to constrict illegal } \\
\text { trawling and to protect Posidonia oceanica meadows. }\end{array}$ \\
\hline
\end{tabular}


Table 6. Cont.

\begin{tabular}{|c|c|}
\hline Code & Action \\
\hline ACT_Reg_5 & To adopt measures to prevent coastal erosion. \\
\hline ACT_Reg_6 & $\begin{array}{l}\text { To elaborate strategies and programs for the sustainable use of the MPA } \\
\text { territory. }\end{array}$ \\
\hline ACT_Reg_7 & $\begin{array}{l}\text { To adopt measures to facilitate the rescue of animals in distress or } \\
\text { disoriented. }\end{array}$ \\
\hline ACT_Reg_8 & To regulate photo shoots, filming and TV recordings. \\
\hline ACT_Reg_9 & $\begin{array}{l}\text { To launch recovery campaigns of abandoned waste and of the polluted } \\
\text { areas of the MPA. }\end{array}$ \\
\hline ACT_Reg_10 & $\begin{array}{l}\text { To launch eradication campaigns of all invasive or potential invasive } \\
\text { alien plants. }\end{array}$ \\
\hline ACT_Reg_11 & To regulate activities allowed in each MPA zone. \\
\hline ACT_Reg_12 & To organize the tourism fruition system within the MPA. \\
\hline ACT_Reg_13 & $\begin{array}{l}\text { To control and limit ship and boat speed, in order to reduce underwater } \\
\text { noise pollution and the risk of collision with cetaceans and turtles. }\end{array}$ \\
\hline ACT_Reg_14 & To regulate monitoring activities. \\
\hline ACT_Reg_15 & To define identification criteria of fishing gear hallmarking. \\
\hline ACT_Reg_16 & To define a plan for the recovery of ghost fishing gear. \\
\hline ACT_Reg_17 & $\begin{array}{l}\text { To adopt adequate measures to rehabilitate dunes and bars (protection, } \\
\text { signage and maintenance). }\end{array}$ \\
\hline ACT_Reg_18 & To design and create submarine paths. \\
\hline ACT_Reg_19 & To launch seabed cleaning campaigns. \\
\hline ACT_Reg_20 & To regulate technical and scientific research activity. \\
\hline ACT_Reg_21 & To regulate bathing and swimming. \\
\hline ACT_Reg_22 & To regulate guided scuba diving tours. \\
\hline ACT_Reg_23 & To regulate sea-watching activities. \\
\hline ACT_Reg_24 & To regulate recreational boat activities. \\
\hline ACT_Reg_25 & To regulate docking of recreational boats. \\
\hline ACT_Reg_26 & To regulate mooring of recreational boats. \\
\hline ACT_Reg_27 & $\begin{array}{l}\text { To regulate activities of public passenger transport services, sailboat } \\
\text { charters and guided tours. }\end{array}$ \\
\hline ACT_Reg_28 & To regulate professional fishing activities. \\
\hline ACT_Reg_29 & To regulate activities of recreational fishing and ichthyic tourism. \\
\hline ACT_Reg_30 & To regulate whale-watching activities. \\
\hline ACT_Reg_31 & To regulate chartering and leasing, even temporary, of recreational boats. \\
\hline ACT_Reg_32 & $\begin{array}{l}\text { To assess vulnerability and risk to accordingly adopt measures of } \\
\text { prevention, mitigation and adaptation to face consequences of natural } \\
\text { disasters and environmental emergences. }\end{array}$ \\
\hline ACT_Reg_33 & $\begin{array}{l}\text { To define a set of indicators to asses carrying capacity of the MPA during } \\
\text { the summer. }\end{array}$ \\
\hline ACT_Reg_34 & $\begin{array}{l}\text { To regulate authorizations for the development of socio-economic, } \\
\text { tourist, social and cultural activities within the MPA. }\end{array}$ \\
\hline ACT_Reg_35 & $\begin{array}{l}\text { To adopt measures to preserve and protect the archaeologic, historic and } \\
\text { cultural submarine heritage. }\end{array}$ \\
\hline
\end{tabular}


Table 6. Cont.

\begin{tabular}{|c|c|}
\hline Code & Action \\
\hline ACT_Reg_36 & $\begin{array}{l}\text { To adopt temporary protection measures in the areas and during the } \\
\text { reproductive periods of vulnerable species that nest on cliffs or minor } \\
\text { islands, such as ban on entry of boats, bathing prohibition and stop of } \\
\text { recreational and commercial tourist activities. }\end{array}$ \\
\hline ACT_Reg_37 & To tighten controls on sea-water quality. \\
\hline ACT_Reg_38 & $\begin{array}{l}\text { To establish rules and regulations concerning wastewater and } \\
\text { hydrocarbons discharge into the sea. }\end{array}$ \\
\hline ACT_Reg_39 & To circumscribe areas at risk of landslide. \\
\hline ACT_Reg_40 & $\begin{array}{l}\text { To define motor parameters of boats according to the Italian Legislative } \\
\text { Decree No. } 171 / 2005 \text {. }\end{array}$ \\
\hline ACT_Reg_41 & To systematize the mooring infrastructure. \\
\hline \multicolumn{2}{|c|}{ Action category: MONITORING } \\
\hline ACT_Reg_42 & To launch monitoring campaigns to collect data on air quality. \\
\hline ACT_Reg_43 & $\begin{array}{l}\text { To launch monitoring campaigns of habitats and species to guarantee } \\
\text { biodiversity preservation. }\end{array}$ \\
\hline ACT_Reg_44 & $\begin{array}{l}\text { To launch monitoring campaigns of marine and coastal invasive alien } \\
\text { plants. }\end{array}$ \\
\hline ACT_Reg_45 & $\begin{array}{l}\text { To launch monitoring campaigns of geomorphological dynamics of } \\
\text { beach-dune systems and of sandy coastlines. }\end{array}$ \\
\hline ACT_Reg_46 & To launch census and monitoring campaigns of fish species. \\
\hline ACT_Reg_47 & To launch monitoring campaigns of tourist activity impacts. \\
\hline ACT_Reg_48 & $\begin{array}{l}\text { To launch monitoring campaigns of the marine avifauna of conservation } \\
\text { interest. }\end{array}$ \\
\hline ACT_Reg_49 & To launch monitoring campaigns of professional fishing and its impacts. \\
\hline ACT_Reg_50 & $\begin{array}{l}\text { To launch census and monitoring campaigns for the protection of } \\
\text { coralligenous biocenosis. }\end{array}$ \\
\hline ACT_Reg_51 & $\begin{array}{l}\text { To launch census and monitoring campaigns for the protection of } \\
\text { Posidonia oceanica meadows. }\end{array}$ \\
\hline ACT_Reg_52 & To launch monitoring campaigns of fishing and ichthyic tourism. \\
\hline \multicolumn{2}{|c|}{ Action category: PROMOTION, SENSIBILIZATION, INFORMATION AND EDUCATION } \\
\hline ACT_Reg_53 & $\begin{array}{l}\text { To launch awareness-raising campaigns to prevent alien species } \\
\text { importation. }\end{array}$ \\
\hline ACT_Reg_54 & $\begin{array}{l}\text { To launch awareness-raising campaigns for the installation of } \\
\text { low-impact-lighting systems aimed at reducing animal disorientation. }\end{array}$ \\
\hline ACT_Reg_55 & $\begin{array}{l}\text { To launch awareness-raising and information campaigns to protect the } \\
\text { species of the marine and coastal environment. }\end{array}$ \\
\hline ACT_Reg_56 & $\begin{array}{l}\text { To launch awareness-raising and information campaigns to reduce } \\
\text { anthropic disturbance of the avifauna in the MPA. }\end{array}$ \\
\hline ACT_Reg_57 & $\begin{array}{l}\text { To launch awareness-raising and information campaigns to reduce } \\
\text { waste abandonment. }\end{array}$ \\
\hline ACT_Reg_58 & To launch environmental education programs and activities. \\
\hline ACT_Reg_59 & To promote the MPA territory. \\
\hline ACT_Reg_60 & To promote interdisciplinary scientific research projects. \\
\hline ACT_Reg_61 & $\begin{array}{l}\text { To plan awareness-raising, education and training activities on } \\
\text { integrated management of coastal areas. }\end{array}$ \\
\hline
\end{tabular}


Table 6. Cont.

\begin{tabular}{|c|c|}
\hline Code & Action \\
\hline ACT_Reg_62 & $\begin{array}{l}\text { To launch awareness-raising, education and control activities to prevent } \\
\text { material removal from the coast and the sea, according to the Regional } \\
\text { Law 16/2017. }\end{array}$ \\
\hline ACT_Reg_63 & To launch campaigns to promote environmental and landscape heritage. \\
\hline ACT_Reg_64 & $\begin{array}{l}\text { To launch information and promotional campaigns on the economic } \\
\text { activities of the MPA. }\end{array}$ \\
\hline ACT_Reg_65 & $\begin{array}{l}\text { To launch information and promotional campaigns addressed to the } \\
\text { economic actors who work in the MPA. }\end{array}$ \\
\hline ACT_Reg_66 & $\begin{array}{l}\text { To launch awareness-raising campaigns addressed to the operators of } \\
\text { the fishing sector against the abandonment of fishing equipment. }\end{array}$ \\
\hline \multicolumn{2}{|c|}{ Action category: SURVEILLANCE } \\
\hline ACT_Reg_67 & $\begin{array}{l}\text { To organize and intensify the surveillance in the most problematic zones, } \\
\text { paying particular attention on marine and terrestrial areas with } \\
\text { important tourism flows. }\end{array}$ \\
\hline ACT_Reg_68 & To implement the surveillance camera system. \\
\hline ACT_Reg_69 & To launch surveillance campaigns to protect habitats and species. \\
\hline ACT_Reg_70 & To organize and improve the surveillance of the fishing sector. \\
\hline ACT_Reg_71 & To promote poaching suppression. \\
\hline \multicolumn{2}{|c|}{ Action category: INTERINSTITUTIONAL COOPERATION } \\
\hline ACT_Reg_72 & $\begin{array}{l}\text { To encourage national, regional and local initiatives through coordinate } \\
\text { actions of promotion, cooperation and partnership. }\end{array}$ \\
\hline ACT_Reg_73 & $\begin{array}{l}\text { To adopt adequate measures to reinforce regional, national and } \\
\text { international cooperation. }\end{array}$ \\
\hline ACT_Reg_74 & $\begin{array}{l}\text { To coordinate institutional intersectoral activities promoted by } \\
\text { administrative services and regional and local authorities in charge in } \\
\text { the coastal zones. }\end{array}$ \\
\hline ACT_Reg_75 & $\begin{array}{l}\text { To organize access and parking in the MPA according to the } \\
\text { environmental carrying capacity. }\end{array}$ \\
\hline ACT_Reg_76 & $\begin{array}{l}\text { To enhance and coordinate, in cooperation with the surrounding local } \\
\text { entities, the public transportation system that connects the Asinara } \\
\text { Island with the municipalities of Stintino and Porto Torres. }\end{array}$ \\
\hline ACT_Reg_77 & To coordinate the activities for cetacean and sea turtle rescue. \\
\hline
\end{tabular}

\section{Selection of Ecosystem Services for MPAs}

Given the need of guaranteeing coherency and compatibility among the diverse assessments, and the aim of properly integrating ES assessment into the PS in order to update the regulations in ecosystemic terms, this paper proposes a selection of ESs for the "Isola dell'Asinara" MPA based on the Common International Classification of Ecosystem Goods and Services (CICES). CICES consists of a hierarchical scheme for ES classification based on the three main categories of ecosystem services [62]:

1. Provisioning services: Provision of genuine goods, such as food, water, timber, fiber, fuel and other raw materials, but also genetic material and ornamental species;

2. regulation services: Regulation of climate, air quality and water, soil formation, pollination, waste assimilation, and mitigation of natural hazards such as erosion, weeds, etc.;

3. cultural services: Non-material benefits such as heritage and cultural identity, spiritual enrichment and intellectual, aesthetic and recreational values. 
The work has been conducted on the basis of a study realized in the "Isola dell'Asinara" MPA, concerning environmental accounting in Italian marine protected areas (in Italian: "Contabilità ambientale nelle aree marine protette italiane") [63], which assigns an ecological value to environmental heritage and subsequently identifies the ecological functions and the relative ESs that characterize it.

On the basis of data provided by the MPA, a set of ESs has been identified and classified according to the CICES scheme (Table 7). The criterion adopted for ES identification was the influence wielded over them by the protection regime in force within the MPA, and their suitability to MPA management.

Table 7. Proposal of a common Ecosystem Service (ES) classification [64].

\begin{tabular}{cccc}
\hline \multicolumn{2}{c}{ CICES for Ecosystem Accounting } & Class \\
\hline $\begin{array}{c}\text { This column lists } \\
\text { the three main } \\
\text { categories of ES. }\end{array}$ & $\begin{array}{c}\text { This column divides } \\
\text { section categories into } \\
\text { the main types of output } \\
\text { or process. }\end{array}$ & $\begin{array}{c}\text { The group level splits } \\
\text { division categories by } \\
\text { biological, physical or } \\
\text { cultural type or process. }\end{array}$ & $\begin{array}{c}\text { The class level provides further } \\
\text { sub-division of group categories into } \\
\text { biological or material outputs and } \\
\text { bio-physical and cultural processes that } \\
\text { can be linked back to concrete } \\
\text { identifiable service sources. }\end{array}$ \\
\hline
\end{tabular}

The three sections identified by the CICES scheme are: Regulation and maintenance, provisioning and cultural. It must be noticed that these categories are not designed for a specific spatial scale nor for a unique governance level. Thus, the ES assessment needs to be tailored for MPAs and Natura 2000 sites by considering that:

- Terrestrial ES (cultivated crops, surface water for drinking, etc.) are out of the scope of this study;

- the MPA objectives focus more on biodiversity protection rather than on recreational functions and food productions (i.e., fishing).

Tables 8-10 illustrate the match between ES classes and PS actions related to the ES sections "regulation and maintenance", "provisioning" and "cultural", respectively.

Table 8. Association between ES classes and PS actions related to the ES section "provisioning".

\begin{tabular}{l}
\hline \multicolumn{1}{c}{ Section: Provisioning } \\
\hline ES Class \\
\hline Cultivated crops \\
\hline Reared animals and their outputs \\
\hline Wild plants, algae and their outputs \\
\hline Wild animals and their outputs \\
\hline Plants and algae from in-situ aquaculture \\
\hline Animals from in-situ aquaculture \\
\hline Surface water for drinking \\
\hline Ground water for drinking \\
\hline $\begin{array}{c}\text { Fibers and other materials from plants, algae } \\
\text { and animals for direct use or processing }\end{array}$ \\
\\
\hline Materials from plants, algae and animals for \\
agricultural use \\
\hline Genetic materials from all biota \\
\hline Surface water for non-drinking purposes \\
\hline Ground water for non-drinking purposes \\
\hline Plant-based resources \\
\hline Animal-based resources \\
\hline
\end{tabular}


Table 9. Association between ES classes and PS actions related to the ES section "regulation and maintenance".

\begin{tabular}{|c|c|}
\hline \multicolumn{2}{|c|}{ Section: Regulation and Maintenance } \\
\hline ES Class & PS Action \\
\hline \multicolumn{2}{|l|}{$\begin{array}{l}\text { Bio-remediation by micro-organisms, algae, plants, } \\
\text { and animals }\end{array}$} \\
\hline \multirow{3}{*}{$\begin{array}{l}\text { Filtration/sequestration/storage/accumulation by } \\
\text { ecosystems }\end{array}$} & To regulate the management of stranded Posidonia oceanica \\
\hline & $\begin{array}{l}\text { Positioning of landing stages of buoys for the mooring of } \\
\text { recreational boats in proximity of the Asinara island, in order } \\
\text { to preserve Posidonia oceanica habitats }\end{array}$ \\
\hline & $\begin{array}{l}\text { Realization of artificial submerged barriers in order to } \\
\text { constrict illegal trawling and to protect Posidonia oceanica } \\
\text { meadows }\end{array}$ \\
\hline \multicolumn{2}{|l|}{$\begin{array}{l}\text { Dilution by atmosphere, freshwater and marine } \\
\text { ecosystems }\end{array}$} \\
\hline \multicolumn{2}{|l|}{ Mediation of smell/noise/visual impacts } \\
\hline Mass stabilization and control of erosion rates & To circumscribe areas at risk of landslide \\
\hline \multicolumn{2}{|l|}{ Buffering and attenuation of mass flows } \\
\hline \multicolumn{2}{|l|}{ Hydrological cycle and water flow maintenance } \\
\hline \multirow{5}{*}{ Flood protection } & To regulate the management of stranded Posidonia oceanica. \\
\hline & To adopt measures to prevent coastal erosion. \\
\hline & $\begin{array}{l}\text { To adopt adequate measures to rehabilitate dunes and bars } \\
\text { (protection, signage and maintenance) }\end{array}$ \\
\hline & $\begin{array}{c}\text { To assess vulnerability and risk to accordingly adopt } \\
\text { measures of prevention, mitigation and adaptation to face } \\
\text { consequences of natural disasters and environmental } \\
\text { emergencies }\end{array}$ \\
\hline & $\begin{array}{l}\text { To launch monitoring campaigns of geomorphological } \\
\text { dynamics of beach-dune systems and of sandy coastlines }\end{array}$ \\
\hline \multirow{4}{*}{ Storm protection } & To regulate the management of stranded Posidonia oceanica \\
\hline & To adopt measures to prevent coastal erosion. \\
\hline & $\begin{array}{l}\text { To adopt adequate measures to rehabilitate dunes and bars } \\
\text { (protection, signage and maintenance) }\end{array}$ \\
\hline & $\begin{array}{c}\text { To assess vulnerability and risk to accordingly adopt } \\
\text { measures of prevention, mitigation and adaptation to face } \\
\text { consequences of natural disasters and environmental } \\
\text { emergencies }\end{array}$ \\
\hline \multicolumn{2}{|l|}{ Ventilation and transpiration } \\
\hline \multicolumn{2}{|l|}{ Pollination and seed dispersal } \\
\hline \multirow{8}{*}{ Maintaining nursery populations and habitats } & $\begin{array}{l}\text { To adopt protection and conservation measures for habitats } \\
\text { and species }\end{array}$ \\
\hline & $\begin{array}{l}\text { To elaborate strategies and programs for the sustainable use } \\
\text { of the MPA territory }\end{array}$ \\
\hline & $\begin{array}{l}\text { To adopt measures to facilitate the rescue of animals in } \\
\text { distress or disoriented }\end{array}$ \\
\hline & To regulate photo shoots, filming and TV recordings \\
\hline & $\begin{array}{l}\text { To launch eradication campaigns of all invasive or potential } \\
\text { invasive alien plants }\end{array}$ \\
\hline & To regulate activities allowed in each MPA zone \\
\hline & To organize the tourism fruition system within the MPA \\
\hline & $\begin{array}{l}\text { To control and limit ship and boat speed, in order to reduce } \\
\text { underwater noise pollution and the risk of collision with } \\
\text { cetaceans and turtles }\end{array}$ \\
\hline
\end{tabular}


Table 9. Cont.

Section: Regulation and Maintenance

\begin{tabular}{cc}
\hline Section: Regulation and Maintenance \\
\hline ES Class & PS Action \\
\cline { 2 - 2 } & To regulate monitoring activities \\
\cline { 2 - 2 } & To design and create submarine paths \\
\cline { 2 - 2 } & To launch seabed cleaning campaigns \\
\cline { 2 - 2 } & To regulate technical and scientific research activity \\
\cline { 2 - 2 } & To regulate bathing and swimming \\
\cline { 2 - 2 } & To regulate sea-watching activities \\
\hline & To regulate recreational boat activities \\
\hline & To regulate mooring of recreational boats \\
\hline
\end{tabular}

To regulate activities of public passenger transport services, sailboat charters and guided tours

To regulate professional fishing activities

To regulate activities of recreational fishing and ichthyic tourism

To regulate whale-watching activities

To regulate chartering and leasing, even temporary, of recreational boats

To define a set of indicators to asses carrying capacity of the MPA during the summer

To regulate authorizations for the development of socio-economic, tourist, social and cultural activities within the MPA

To adopt temporary protection measures in the areas and during the reproductive periods of vulnerable species that nest on cliffs or minor islands, such as ban on entry of boats, bathing prohibition and stop of recreational and commercial tourist activities

To systematize the mooring infrastructure

To launch monitoring campaigns of habitats and species to guarantee biodiversity preservation

To launch monitoring campaigns of marine and coastal invasive alien plants

To launch census and monitoring campaigns of fish species

To launch monitoring campaigns of tourist activity impacts

To launch monitoring campaigns of the marine avifauna of conservation interest.

To launch monitoring campaigns of professional fishing and its impacts.

To launch census and monitoring campaigns for the protection of coralligenous biocenosis

To launch monitoring campaigns of fishing and ichthyic tourism

To launch awareness-raising campaigns to prevent alien species importation 
Table 9. Cont.

\begin{tabular}{|c|c|}
\hline \multicolumn{2}{|c|}{ Section: Regulation and Maintenance } \\
\hline ES Class & PS Action \\
\hline & $\begin{array}{c}\text { To launch awareness-raising campaigns for the installation of } \\
\text { low-impact-lighting systems aimed at reducing animal } \\
\text { disorientation }\end{array}$ \\
\hline & $\begin{array}{l}\text { To launch awareness-raising and information campaigns to } \\
\text { protect the species of the marine and coastal environment }\end{array}$ \\
\hline & $\begin{array}{l}\text { To launch awareness-raising and information campaigns to } \\
\text { reduce anthropic disturbance of the avifauna in the MPA }\end{array}$ \\
\hline & $\begin{array}{l}\text { To launch awareness-raising and information campaigns to } \\
\text { reduce waste abandonment }\end{array}$ \\
\hline & $\begin{array}{c}\text { To plan awareness-raising, education and training activities } \\
\text { on integrated management of coastal areas }\end{array}$ \\
\hline & $\begin{array}{c}\text { To launch awareness-raising, education and control activities } \\
\text { to prevent material removal from the coast and the sea, } \\
\text { according to the Regional Law } 16 / 2017\end{array}$ \\
\hline & $\begin{array}{c}\text { To launch awareness-raising, education and control activities } \\
\text { to prevent material removal from the coast and the sea, } \\
\text { according to the Regional Law } 16 / 2017\end{array}$ \\
\hline & $\begin{array}{c}\text { To launch campaigns to promote environmental and } \\
\text { landscape heritage }\end{array}$ \\
\hline & $\begin{array}{l}\text { To launch information and promotional campaigns on the } \\
\text { economic activities of the MPA }\end{array}$ \\
\hline & $\begin{array}{l}\text { To launch information and promotional campaigns } \\
\text { addressed to the economic actors who work in the MPA }\end{array}$ \\
\hline & $\begin{array}{c}\text { To launch awareness-raising campaigns addressed to the } \\
\text { operators of the fishing sector against the abandonment of } \\
\text { fishing equipment }\end{array}$ \\
\hline & To promote poaching suppression \\
\hline \multicolumn{2}{|l|}{ Pest control } \\
\hline \multicolumn{2}{|l|}{ Disease control } \\
\hline \multicolumn{2}{|l|}{ Weathering processes } \\
\hline \multicolumn{2}{|l|}{ Decomposition and fixing processes } \\
\hline \multicolumn{2}{|l|}{ Chemical condition of freshwaters } \\
\hline \multirow{11}{*}{ Chemical condition of salt waters } & $\begin{array}{l}\text { To adopt protection and conservation measures for habitats } \\
\text { and species }\end{array}$ \\
\hline & $\begin{array}{l}\text { Positioning of landing stages of buoys for the mooring of } \\
\text { recreational boats in proximity of the Asinara island, in order } \\
\text { to preserve Posidonia oceanica habitats }\end{array}$ \\
\hline & $\begin{array}{l}\text { Realization of artificial submerged barriers in order to } \\
\text { constrict illegal trawling and to protect Posidonia oceanica } \\
\text { meadows }\end{array}$ \\
\hline & $\begin{array}{l}\text { To elaborate strategies and programs for the sustainable use } \\
\text { of the MPA territory }\end{array}$ \\
\hline & $\begin{array}{c}\text { To launch recovery campaigns of abandoned waste and of } \\
\text { the polluted areas of the MPA }\end{array}$ \\
\hline & $\begin{array}{l}\text { To launch eradication campaigns of all invasive or potential } \\
\text { invasive alien plants }\end{array}$ \\
\hline & To regulate activities allowed in each MPA zone \\
\hline & To organize the tourism fruition system within the MPA \\
\hline & To regulate monitoring activities \\
\hline & To launch seabed cleaning campaigns \\
\hline & To regulate bathing and swimming \\
\hline
\end{tabular}


Table 9. Cont.

\begin{tabular}{|c|c|}
\hline \multicolumn{2}{|c|}{ Section: Regulation and Maintenance } \\
\hline \multirow[b]{3}{*}{ ES Class } & To regulate recreational boat activities \\
\hline & $\begin{array}{l}\text { To regulate activities of public passenger transport services, } \\
\text { sailboat charters and guided tours }\end{array}$ \\
\hline & PS Action \\
\hline & $\begin{array}{c}\text { To regulate chartering and leasing, even temporary, of } \\
\text { recreational boats }\end{array}$ \\
\hline & $\begin{array}{l}\text { To define a set of indicators to asses carrying capacity of the } \\
\text { MPA during the summer }\end{array}$ \\
\hline & $\begin{array}{l}\text { To regulate authorizations for the development of } \\
\text { socio-economic, tourist, social and cultural activities within } \\
\text { the MPA }\end{array}$ \\
\hline & To tighten controls on sea-water quality. \\
\hline & $\begin{array}{l}\text { To establish rules and regulations concerning wastewater } \\
\text { and hydrocarbons discharge into the sea. }\end{array}$ \\
\hline & $\begin{array}{l}\text { To define motor parameters of boats according to the Italian } \\
\text { Legislative Decree No. } 171 / 2005\end{array}$ \\
\hline & To launch monitoring campaigns of tourist activity impacts \\
\hline & $\begin{array}{l}\text { To launch census and monitoring campaigns for the } \\
\text { protection of Posidonia oceanica meadows }\end{array}$ \\
\hline & $\begin{array}{l}\text { To launch awareness-raising and information campaigns to } \\
\text { reduce waste abandonment }\end{array}$ \\
\hline & $\begin{array}{l}\text { To plan awareness-raising, education and training activities } \\
\text { on integrated management of coastal areas }\end{array}$ \\
\hline & $\begin{array}{c}\text { To launch campaigns to promote environmental and } \\
\text { landscape heritage }\end{array}$ \\
\hline & $\begin{array}{l}\text { To launch information and promotional campaigns on the } \\
\text { economic activities of the MPA }\end{array}$ \\
\hline & $\begin{array}{l}\text { To launch information and promotional campaigns } \\
\text { addressed to the economic actors who work in the MPA }\end{array}$ \\
\hline \multirow{3}{*}{$\begin{array}{l}\text { Global climate regulation by reduction of } \\
\text { greenhouse gas concentrations }\end{array}$} & $\begin{array}{l}\text { Positioning of landing stages of buoys for the mooring of } \\
\text { recreational boats in proximity of the Asinara island, in order } \\
\text { to preserve Posidonia oceanica habitats. }\end{array}$ \\
\hline & $\begin{array}{l}\text { Realization of artificial submerged barriers in order to } \\
\text { constrict illegal trawling and to protect Posidonia oceanica } \\
\text { meadows }\end{array}$ \\
\hline & $\begin{array}{c}\text { To launch census and monitoring campaigns for the } \\
\text { protection of Posidonia oceanica meadows }\end{array}$ \\
\hline \multirow{4}{*}{ Micro and regional climate regulation } & $\begin{array}{l}\text { Positioning of landing stages of buoys for the mooring of } \\
\text { recreational boats in proximity of the Asinara island, in order } \\
\text { to preserve Posidonia oceanica habitats }\end{array}$ \\
\hline & $\begin{array}{l}\text { Realization of artificial submerged barriers in order to } \\
\text { constrict illegal trawling and to protect Posidonia oceanica } \\
\text { meadows }\end{array}$ \\
\hline & To launch monitoring campaigns to collect data on air quality \\
\hline & $\begin{array}{l}\text { To launch census and monitoring campaigns for the } \\
\text { protection of Posidonia oceanica meadows }\end{array}$ \\
\hline
\end{tabular}


Table 10. Association between ES classes and PS actions related to the ES section "cultural".

\begin{tabular}{|c|c|}
\hline \multicolumn{2}{|c|}{ Section: Cultural } \\
\hline ES Class & PS Action \\
\hline $\begin{array}{l}\text { Experiential use of plants, animals and } \\
\text { land-/sea-scapes in different environmental settings }\end{array}$ & $\begin{array}{l}\text { To adopt protection and conservation measures for } \\
\text { habitats and species }\end{array}$ \\
\hline \multirow{10}{*}{$\begin{array}{l}\text { Physical use of land-/sea-scapes in different } \\
\text { environmental settings }\end{array}$} & $\begin{array}{l}\text { To adopt protection and conservation measures for } \\
\text { habitats and species }\end{array}$ \\
\hline & $\begin{array}{c}\text { To define identification criteria of fishing gear } \\
\text { hallmarking. }\end{array}$ \\
\hline & To define a plan for the recovery of ghost fishing gear \\
\hline & To regulate bathing and swimming \\
\hline & To regulate guided scuba diving tours \\
\hline & To regulate sea-watching activities \\
\hline & To regulate recreational boat activities \\
\hline & To promote the MPA territory \\
\hline & $\begin{array}{l}\text { To launch campaigns to promote environmental and } \\
\text { landscape heritage }\end{array}$ \\
\hline & $\begin{array}{c}\text { To launch awareness-raising campaigns addressed to } \\
\text { the operators of the fishing sector against the } \\
\text { abandonment of fishing equipment }\end{array}$ \\
\hline Scientific & $\begin{array}{l}\text { To promote interdisciplinary scientific research } \\
\text { projects }\end{array}$ \\
\hline \multirow{3}{*}{ Educational } & $\begin{array}{l}\text { To launch environmental education programs and } \\
\text { activities }\end{array}$ \\
\hline & $\begin{array}{l}\text { To plan awareness-raising, education and training } \\
\text { activities on integrated management of coastal areas }\end{array}$ \\
\hline & $\begin{array}{l}\text { To launch awareness-raising, education and control } \\
\text { activities to prevent material removal from the coast } \\
\text { and the sea, according to the Regional Law 16/2017 }\end{array}$ \\
\hline Heritage, cultural & $\begin{array}{l}\text { To adopt measures to preserve and protect the } \\
\text { archaeologic, historic and cultural submarine heritage }\end{array}$ \\
\hline \multirow{5}{*}{ Entertainment } & To regulate bathing and swimming \\
\hline & To regulate guided scuba diving tours \\
\hline & To regulate sea-watching activities \\
\hline & To regulate recreational boat activities \\
\hline & To regulate whale-watching activities \\
\hline Aesthetic & $\begin{array}{l}\text { To launch awareness-raising, education and control } \\
\text { activities to prevent material removal from the coast } \\
\text { and the sea, according to the Regional Law 16/2017 }\end{array}$ \\
\hline \multicolumn{2}{|l|}{ Symbolic } \\
\hline \multicolumn{2}{|l|}{ Sacred and/or religious } \\
\hline \multicolumn{2}{|l|}{ Existence } \\
\hline Bequest & \\
\hline
\end{tabular}

Tables 8-10 show that the previously defined actions of the PS match all the three ES sections and that the majority of the actions refer to the "regulation and maintenance" and "cultural" ES sections. In particular, the highest number of matches is observable in the classes "maintaining nursery populations and habitats" and "chemical condition of salt waters" in the section "regulation and maintenance" and in the class "physical use of land/sea-scapes in different environmental settings" in the section "cultural". However, not all the ES classes are matched to PS actions. Nevertheless, some of them are relevant for defining an appropriate management of the MPA. For example, "wild animals 
and their outputs", "bio-remediation by micro-organisms, algae, plants and animals", "dilution by atmosphere, freshwater and marine ecosystems", "symbolic", "existence" and "bequest".

Subsequently to this classification, in order to assess the management of the MPA, ES classes have been grouped into five macro-themes according to the proposal of the Millennium Ecosystem Assessment proposal [62] for urban, coastal and marine areas as follows:

- Tourism fruition and eco-tourism;

- fish biomass supply for business or entertainment purposes;

- climate regulation;

- water quality regulation;

- landscape and cultural heritage.

These macro-themes have been assessed through a methodological approach similar to the one that guided the environmental assessment of the PS. Indeed, they have been described through a proper summary sheet with the aim of identifying a set of objectives in addition to those already defined in the PS. In this way, it is possible to update the regulations according to an "ecosystemic" perspective. Table 11 provides an example of a summary sheet for the ES " $k$ ".

Table 11. Example of a summary sheet for the ES " $k$ ".

\begin{tabular}{|c|c|}
\hline \multicolumn{2}{|c|}{$\begin{array}{l}\text { The introductive section qualitatively describes the ecosystem Service } \mathrm{K} \text { in the analyzed territorial } \\
\text { context. Moreover, the activities that best represent the analyzed ES are identified and articulated in } \\
\text { specific aspects. These provide a quantitative analysis based on appropriate indicators. }\end{array}$} \\
\hline Activity 1 & \\
\hline \multicolumn{2}{|c|}{ This section provides a brief qualitative description of the activity and its characterizing aspects. } \\
\hline \multirow[t]{2}{*}{ ES Class } & Measure unit \\
\hline & Activity $n$ \\
\hline \multicolumn{2}{|c|}{ This section provides a brief qualitative description of the activity and its characterizing aspects. } \\
\hline ES Class $\quad$ indicator & Measure unit \\
\hline \multicolumn{2}{|l|}{ Flow calculation } \\
\hline
\end{tabular}

Among the previously identified "ecosystemic macro-themes", for the purpose of this study, it is worth focusing on the following:

- Fish biomass supply for business or entertainment purposes;

- landscape fruition for recreational activities (bathing, diving and yachting) and scientific/educational purposes.

In the operational phase, after identifying and mapping where each ES fruition occurs in order to analyze each ES macro-theme, an interview sample was realized with the aim of monitoring anthropic pressures related to ES fruition. Data collection focused on bathing, scuba diving, professional and small-scale fishing and yachting and relied on fieldwork and interviews conducted in the MPA headquarters, especially through:

- Questionnaires to users (i.e., tourists and scuba divers);

- collection of information and documentation related to financial reports, studies and resource exploitation in the MPA headquarters. This part was conducted by the MPA staff in collaboration with the University of Genova; 
- analysis of the documentation on the authorizations granted by the MPA in order to assess anthropic pressures and to gather information concerning the typology of the related operator or user;

- outline of a new authorization system for the simultaneous collection of information about the authorization-release procedure and of all the data needed for the application of the environmental accountability [63].

Human benefits have been assessed according to an anthropocentric approach. In particular, those that derive from ES fruition by operators, tourists and visitors of the MPA were considered as "environmental benefits" and thus evaluated in monetary terms. Differently, biophysical benefits (i.e., those related to the environment and not to humans) were assessed according to an eco-centric approach, which is currently being developed by the Department of Earth Sciences of Environment and Life of the University of Genova within a number of projects, such as GIREPAM. Environmental benefits deriving from the use of the MPA natural heritage have been re-classified on the base of the ES from which they originate [63].

Tables 12 and 13 show the summary sheets related to "tourism fruition" and "fish biomass supply for business or entertainment purposes", elaborated as an example of the previously illustrated analysis.

Table 12. Summary sheet related to "tourism fruition".

ES "tourism fruition and eco-tourism"

The "Isola dell'Asinara" MPA allows the following tourism activities:

Bathing. According to article 11, bathing is forbidden in zone A, and allowed in zones B and C, according to the ordinances of the of the competent maritime authority.

Diving. According to articles 12 and 13 of the regulations, non-organized scuba diving is forbidden. Scuba diving tours are allowed exclusively in zones $B$ and $C$ during the day and at night, prior authorization and according to the procedures provided in the same regulations.

Recreational boats. According to article 14 of the regulations, navigation is allowed to recreational boats with inboard engine exclusively in zone $\mathrm{C}$ and in the entry corridors to the mooring of "La Reale" and "Cala d'Oliva", prior authorization and according to the procedure provided in the same regulations.

Bathing

Since in the "Isola dell'Asinara" seaside facilities are absent, users mainly bath in "Cala Sabina", "Cala d'Oliva" and "dell'Ossario" beaches, which are also included in guided tours. These beaches accommodate the majority of bathers, because access to other sites is more complicated.

The yearly number of bathers, obtained through monitoring activity, is estimated to be approximately 44,450 . During the summer of 2016, a survey was conducted on a sample of 343 bathers. They were all tourists, since the island has only one resident.

$77 \%$ of the respondents were long-stay tourists, the average of their stay in Sardinia was 11 days, of which only one was spent in the MPA. Among them, 15\% spent their holidays in a second home, $31 \%$ rented a house and $44 \%$ chose other options (i.e., hotel, bed and breakfast, etc.). The remaining $23 \%$ of the interviewees were one-day tourists.

Figure 5 shows tourist distribution according to the following categories of tourists: (i) Usual stay; (ii) occasional stay; (iii) usual one-day stay; (iv) occasional one-day stay.

Thus, among the visitors of the "Isola dell'Asinara" MPA every year, 76\% are occasional tourists. With respect to the origin, 95\% of bathers are residents in Italy (of them, 25\% are from Sardinia and 38\% from the north of Italy). All the interviewees consider the MPA important or even a priority. 
Table 12. Cont.

\begin{tabular}{ccc}
\hline Class type & Indicator & Measure unit \\
\hline $\begin{array}{c}\text { Landscape fruition for recreational } \\
\text { and scientific activities. }\end{array}$ & No. of visits. & $\begin{array}{c}\text { Average annual attendances } \\
\text { (2014-2016 period). }\end{array}$ \\
\hline & Scuba Diving &
\end{tabular}

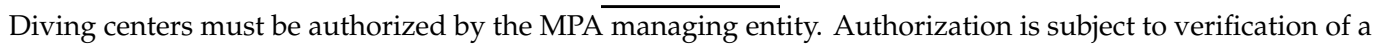
number of specific requirements for diving centers.

In order to protect the seabed, the managing entity monitors underwater activities, identifies dive sites and mooring points, and establishes the maximum number of dives per day and of the marine vessels daily employable by each diving center.

The number of dives per day is fixed at 24 (intended as single plunges), for each of the 25 sites identified by the managing entity. The maximum number of diving centers authorized every year is 5 , and the maximum number of marine vessels for each center is 2.

During the three-year-period 2014-2016, the annual average of dives was 2223.

With the aim of deeply analyzing habits of scuba divers, and how they perceive the MPA, a sample of 61 scuba divers were interviewed; $67 \%$ of them were men, and $55 \%$ were aged between 30 and 50 . The majority of divers (92\%) were from Italy, and $87 \%$ were tourists who were staying in Sardinia; $62 \%$ of divers considered the institution of the MPA a priority, whereas the remaining $38 \%$ considered it important but not a priority.

\begin{tabular}{ccc}
\hline Class type & Indicator & Measure unit \\
\hline $\begin{array}{c}\text { Landscape fruition for recreational } \\
\text { and scientific activities. }\end{array}$ & No. of visits. & $\begin{array}{c}\text { Average annual attendances } \\
\text { (2014-2016 period). }\end{array}$ \\
\hline
\end{tabular}

\section{Flow calculation}

The flow of the "tourist fruition" ES is calculated through the numbers of users of each fruition category.

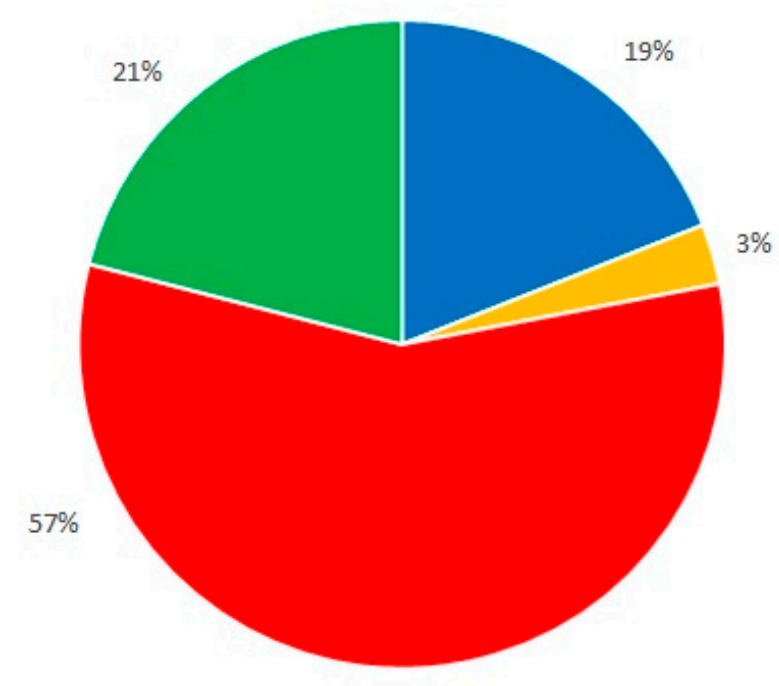

- Occasional one-day stay

= Usual one-day stay

- Occasional stay

- Usual stay

Figure 5. Tourists' stay distribution. Source: Authors' elaboration. 
Table 13. Summary sheet related to "fish biomass supply for business or entertainment purposes".

\begin{tabular}{|c|c|}
\hline \multicolumn{2}{|c|}{ ES: "Fish Biomass Supply for Business or Entertainment Purposes" } \\
\hline $\begin{array}{r}\text { Profe } \\
\text { The number of fishing boats that } \mathrm{r} \\
27 \% \text { are made of fiber }\end{array}$ & $\begin{array}{l}\text { Small-Scale Fishing Related to the ES } \\
\text { the MPA is } 26 \text {, of which } 73 \% \text { are wooden vessels and the remaining } \\
\text { ne average length is } 8.76 \mathrm{~m} \text {, and the propellant is diesel. }\end{array}$ \\
\hline \multicolumn{2}{|c|}{ The regulations of the "Isola dell'Asinara" MPA establishes that: } \\
\hline $\begin{array}{l}\text { - Professional small-scale fish } \\
\text { - } \quad \text { trawling, purse-seine and fis } \\
\text { - } \\
\text { aquaculture and active repo } \\
\text { professional small-scale fis } \\
\text { municipality lists of the MPt }\end{array}$ & $\begin{array}{l}\text { rbidden in zone A; } \\
\text { ith light sources is forbidden; } \\
\text { n are forbidden; } \\
\text { allowed in zones B and C only to the fisheries registered in the } \\
\text { ding to the procedures established by the regulations. }\end{array}$ \\
\hline \multicolumn{2}{|c|}{$\begin{array}{l}\text { With regard to the calculation of fish biomass, data are obtained through visual census campaigns (conducted } \\
\text { by the MPA). In particular, the MPA signed an agreement with the Environmental Office of Corsica (OEC, } \\
\text { Managing Entity of the Natural Reservation of the Strait of Bonifacio, France), to monitor the fish fauna of the } \\
\text { SAC ITB010082 "Isola dell'Asinara" and the SPA ITB010001 "Isola Asinara". }\end{array}$} \\
\hline \multicolumn{2}{|c|}{$\begin{array}{l}\text { The methodology adopted was the direct count via the "visual census" technique, choosing fixed circular } \\
\text { points and areas of } 100 \mathrm{~m}^{2} \text {, with a depth between } 10 \text { and } 20 \mathrm{~m} \text {. Each fixed point was determined by using a } \\
\text { rope of } 11.3 \mathrm{~m} \text { length, corresponding to the diameter of a circle whose area is } 100 \mathrm{~m}^{2} . \text { The biomass was } \\
\text { calculated on the basis of density data, conferring to each individual of each species an average weight } \\
\text { according to its size class. }\end{array}$} \\
\hline \multicolumn{2}{|c|}{$\begin{array}{l}\text { By multiplying the biomass value (calculated for area units) by the areas, the total amount of fish biomass was } \\
\text { obtained: } 943 \text { tons of carbon, corresponding to } 3.63 \% \text { of the benthonic biomass stored in the MPA. }\end{array}$} \\
\hline \multicolumn{2}{|c|}{$\begin{array}{c}\text { This amount is distributed mainly on the biocoenosis of Posidonia oceanica, on infralittoral algae and on coastal } \\
\text { detrital. }\end{array}$} \\
\hline \multicolumn{2}{|c|}{$\begin{array}{l}\text { Calculation of the fish stock underestimates the real value, because the "visual census" technique cannot detect } \\
\text { some species, as the pelagic ones. Thus, the species captured by professional, small-scale and leisure fishers } \\
\text { should be added to the results obtained with this methodology. However, even in this case, the sum would } \\
\text { underestimate the real stock, because these catches would not represent the entirety of the individuals that } \\
\text { compose the stock. }\end{array}$} \\
\hline Class type & Measure unit \\
\hline Wild animals and their outputs & Quantity of fish caught \\
\hline 2014 and 2016 & $\begin{array}{l}\text { Flow calculation } \\
\text { outs" ES was calculated by previous studies conducted by the AMP } \\
\text { on small-scale professional fishing in the three-year period between } \\
\text { ted quantity of fish caught was of } 61,562 \mathrm{~kg} / \text { year. }\end{array}$ \\
\hline
\end{tabular}

Definition of "Ecosystemic objectives" was realized on the basis of the strategy of Agenda 2030 towards sustainable development (Agenda 2030 is an action program joined by 193 ONU countries in September 2015. Agenda 2030 strongly highlights the unsustainability of current economic, environmental and social development models. This vision shifts away from the common idea that sustainable development is just an environmental issue by simultaneously integrating the diverse development dimensions into one coherent vision. The agenda gathers 17 Sustainable Development Goals (SDGs) into an action program articulated in 169 "targets" or "goals". The objectives were launched in 2016, and the subscribing countries committed themselves to achieve them by 2030). In particular, with the aim of defining the "ecosystemic objectives" referring to the studied MPA, the Sustainable Development Goals of Agenda 2030 refer to the themes on which the case study focuses. They have been selected and linked to the macro-themes previously defined. The selected goals are the following:

- Goal 7: Ensure access to affordable, reliable, sustainable and modern energy for all;

- Goal 13: Take urgent action to combat climate change and its impacts;

- Goal 14: Conserve and sustainably use the oceans, seas and marine resources for sustainable development. 
Subsequently, each SDG has been matched with the previously identified macro-themes. Table 14 shows the definition of the ecosystem objectives in relation to the ES chosen for the case study and in correspondence with the selected SDG. These objectives are drawn from the SDGs, but are carefully rephrased in order to be adapted to the context.

Table 14. Ecosystemic objectives.

\begin{tabular}{|c|c|c|}
\hline ES macro-themes & SDG & Ecosystemic Objective \\
\hline Touristic fruition & $\begin{array}{l}\text { Goal } 14 \\
\text { Conserve and sustainably use the } \\
\text { oceans, seas and marine resources } \\
\text { for sustainable development }\end{array}$ & $\begin{array}{l}\text { Significantly prevent and reduce } \\
\text { marine pollution; } \\
\text { - Efficiently regulate fishing activities; } \\
\text { - } \\
\text { Improve the economic benefits deriving } \\
\text { from activities like fishing, aquaculture } \\
\text { and tourism through the sustainable use } \\
\text { of marine resources. }\end{array}$ \\
\hline $\begin{array}{l}\text { Fish biomass supply for business } \\
\text { or entertainment purposes }\end{array}$ & $\begin{array}{l}\text { Goal } 14 \\
\text { Conserve and sustainably use the } \\
\text { oceans, seas and marine resources } \\
\text { for sustainable development }\end{array}$ & $\begin{array}{ll}\text { - Efficiently regulate fishing activities; } \\
\text { - Significantly prevent and reduce } \\
\text { marine pollution; } \\
\text { Ensure access to natural resources and } \\
\text { marine markets to small-scale fishermen. }\end{array}$ \\
\hline Climate regulation & $\begin{array}{c}\text { Goal } 13 \\
\text { Take urgent action to combat } \\
\text { climate change and its impacts }\end{array}$ & $\begin{array}{l}\text { - Integrate the regulations with measures } \\
\text { to contrast climate change. }\end{array}$ \\
\hline $\begin{array}{l}\text { Energy production from } \\
\text { renewable resources }\end{array}$ & $\begin{array}{c}\text { Goal } 7 \\
\text { Ensure access to affordable, } \\
\text { reliable, sustainable and modern } \\
\text { energy for all }\end{array}$ & $\begin{array}{c}\text { - Promote the use of renewable energy in } \\
\text { the regulations }\end{array}$ \\
\hline
\end{tabular}

\section{Discussion}

In this section, results previously obtained and presented are discussed, highlighting the main issues that characterized the two phases of the research. The results offer a way to cope with the critical issues related to the definition of MPA regulations, identified in the previous sections.

The research was articulated into two phases: In the first phase, the methodological approach to update the regulation in the light of Natura 2000 conservation measures was defined; in the second phase, the analysis of the constitutive elements of the PS and their assessment in light of the ESs was conducted.

Concerning the first phase of the research, it is worth noting the following two significant results:

- The integration of the conservation measures provided in Natura 2000 management plans, and in the ICZM protocol and ISEA project into the regulations;

- the involvement and active participation of competent authorities, public bodies, stakeholders and experienced actors-who contributed to regulation improvement by virtue of their diverse needs and visions-which reflect the contrast between environmental protection and socio-economic development. It is important to underline that this moment is not for actors to passively approve decisions already taken according to a top-down approach, but it constitutes a valuable opportunity to share knowledge among stakeholders characterized by diverse backgrounds. It is during this phase that the PS process swings into action, by actually designing the new regulation proposal. Participation is essential to effectively integrate conservation measures and sectoral policies because norms are, in this way, assessed from a legislative point of view and interpreted in the light of their impacts on MPA users' daily life. For this reason, participation is strongly encouraged from the very first steps of the PS definition process. Therefore, sharing is not limited only to results, but it also includes the working methodology. 
The two results reported above allow the overcoming of some critical issues that arose during the construction of the PS:

- The overlapping of local, regional and national competencies. In particular, while the draft of the Natura 2000 management plans is produced by municipalities, their approval is entitled to regional administrations. Similarly, MPA regulations are proposed by the MPA authority, but they are approved by the MATTM. Interaction of diverse authorities complicates the process and entails numerous difficulties, such as the fragmentation and sectorization that characterize the planning and management tools in force;

- lack of operational objectives and actions in the regulations in force, which are able to adequately address a number of territorial problems and issues related to the allowed activities in the MPA. Response to this criticism is currently offered by the annual procedural guidelines, which establish detailed norms and operational conditions for the activities allowed in the MPA. In this sense, the regulation updating responds to the territorial problems and issues related to the allowed activities in the MPA by integrating the indications of the annual procedural guidelines into the new regulations.

Concerning the second phase of the research, it is worth noting the following three significant results:

- Acquisition of knowledge and awareness of ESs and of their potential contribution to human wellbeing. This is obtained through a set of objectives oriented to promote and protect the natural capital of the MPA by giving the regulation updating an ecosystem focus. In fact, it is fundamental to orient human actions to a sustainable use of ES in order to conserve their flows, especially considering that their economy relies on specific ESs (i.e., agriculture and fishing are strictly linked to provisioning ESs, tourism takes advantage of cultural ESs, etc.). With reference to this, "ecosystemic objectives" are defined on the basis of ES and are contextualized in the area of the case study coherently with the regulation actions defined in the PS. This represents the pivotal element for the regulation process to update coherently with the EU guidelines regarding ESs. In particular, with regard to the ES "climate regulation", it was necessary to define a corresponding objective aiming at integrating measures to combat climate change into the regulations. This aspect was totally absent in the existing regulations; thus, it represents an innovation with respect to the "traditional" issues that arose during the implementation of the PS;

- the formulation of a set of ecosystemic objectives and actions in coherence with Agenda 2030 objectives. This connection allowed addressing the existing objectives to specific future challenges (as in the case of objectives related to fishing in light of Objective 14 of Agenda 2030 and the fish biomass supply for business or entertainment purposes).

\section{Conclusions and Suggestions for Further Research}

In light of the previously discussed results, the main obstacles to efficient MPA management are the high variety of objectives regarding protection and development of MPAs and the need to provide users with information about norms and rules concerning the sustainable fruition of these areas. The need to overcome these discrepancies and to simultaneously facilitate users' fruition, by reducing information fragmentation, called for the construction of a dynamic and interdisciplinary instrument able to consider, in an integrated way, all the ecosystem fragilities, the coastal landscape and the human impacts on them.

The proposed conceptual approach represents the starting point for the definition of guidelines on the systematic application of the PS model to spatial planning and to the management of natural areas characterized by an overlapping of diverse normative levels.

Thus, governance and management of marine areas can be innovated according to a holistic territorial vision, able to efficiently contrast biodiversity loss and ecosystem degradation.

Possible further research projects can be developed according to this vision, as, for example: 
- The definition of a monitoring system related to the regulation implementation, in order to assess the impacts of the coastal ecosystem management on ESs;

- ES measurement through adequate accountability and statistical methods to support the decisional process. Indeed, notwithstanding their fundamental role for socio-economic development, the importance of ecosystems for human wellbeing is currently not adequately evaluated, especially at planning and regulation levels [65]. Indeed, ecosystems provide vital support to life quality, and their functions and services can be assessed in monetary terms thus including the value of natural capital in resource management and spatial planning. ES assessment should take into account ecosystem mapping, anthropic pressures that threaten them and interactions between natural capital and its potential in terms of ES provision. This requires the definition of a set of adequate and representative indicators [66];

- ES monetary assessment. In this sense, it is necessary to re-consider the whole management process in order to identify and highlight ES value, and to understand the role of their safeguarding in influencing their quality and quantity in relation to an improvement of the natural capital [22], and also in economic terms;

- the introduction of an evaluation procedure for the MPA regulations. The proposed PS stresses the significative impacts of the regulations on the environment and formulates an innovative approach, inspired by SEA principles and methodology, which allows the inclusion of environmental objectives into the decisional process.

In conclusion, this study proposes an innovative ecosystem approach based on the interaction of diverse disciplines [67] that allows a draft of a new regulation proposal that is more effective with respect to the themes of environmental safeguards and biodiversity protection [68]. It demonstrates that it is possible to realize efficient ex-ante and ex-post assessment for public policies through the development of accounting systems, indicators and assessment methods related to the impact of these policies on the state of the natural capital [66]. This innovative approach can be replicated in other similar contexts for sustainable planning in coastal territories.

Author Contributions: Conceptualization, M.F., V.G., F.I., F.L., S.P. and C.P.; methodology, M.F., F.I., F.L., S.P. and C.P.; investigation, M.F., F.I., F.L., S.P. and C.P.; resources, M.F., V.G., F.I., F.L., S.P. and C.P.; writing-original draft preparation, M.F., F.I., and C.P.; writing—review and editing, F.L. and S.P.; visualization, F.L. and S.P. All authors have read and agreed to the published version of the manuscript.

Funding: This research was funded by the Research project based on the Agreement between Dipartimento di Ingegneria Civile, Ambientale e Architettura (Department of Civil, Environmental Engineering and Architecture, DICAAR) of the University of Cagliari, Italy, and the Autonomous Region of Sardinia, Departmental Office of Environment Protection, finalized to the objectives of the Project "GIREPAM-Integrated Management of Ecological Networks through Parks and Marine Areas" (Programme INTERREG Marittimo Italy-France Maritime 2014-2020, Axis 2).

Acknowledgments: Maddalena Floris gratefully acknowledges Sardinia Regional Government for the financial support of her Ph.D. scholarship. (P.O.R. Sardegna F.S.E. Operational Program of the Autonomous Region of Sardinia, European Social Fund 2014-2020 - Axis III Education and training, Thematic goal 10, Priority of investment 10ii.).

Conflicts of Interest: The authors declare no conflict of interest. The funders had no role in the design of the study; in the collection, analyses, or interpretation of data; in the writing of the manuscript, or in the decision to publish the results.

\section{References}

1. Agardy, T. Information needs for marine protected areas: Scientific and societal. BMS 2000, 66, 875-888. [CrossRef]

2. Agardy, T.; Alder, J.; Dayton, P.; Curran, S.; Kitchingman, A.; Wilson, M.; Catenazzi, A.; Restrepo, J.; Birkeland, C.; Blaber, S.; et al. Coastal System. In Current State and Trends; Global Assessment reports; Island Press: Washington, DC, USA, 2005; Chapter 19; Volume 1, pp. 513-549. 
3. Arkema, K.K.; Guannel, G.; Verutes, G.; Wood, S.A.; Guerry, A.; Ruckelshaus, M.; Kareiva, P.; Lacayo, M.; Silver, J.M.; Lacayo-Emery, M. Coastal habitats shield people and property from sea-level rise and storms. Nat. Clim. Chang. 2013, 3, 913-918. [CrossRef]

4. Australian Government. The Logical Framework Approach, AusGUIDElines, AusAID; AusAID: Canberra, Australia, 2000.

5. Bonvoisin, N. Decision-Making for Sustainable Development: How Assessment Can Help. Available online: https://www.unece.org/fileadmin/DAM/oes/nutshell/2009/6_SusDev.EIA.pdf (accessed on 4 October 2019).

6. Borja, A. Grand challenges in marine ecosystems ecology. Front. Mar. Sci. 2014, 1, 1. [CrossRef]

7. Blackman, R. Project Cycle Management; Tearfund: Teddington, UK, 2003.

8. Brown, A.L.; Thérivel, R. Principles to Guide the Development of Strategic Environmental Assessment Methodology. Impact Assess. Proj. Apprais. 2012, 18, 183-189. [CrossRef]

9. Bussi, F. Progettare in Partenariato. Guida Alla Conduzione di Gruppi di Lavoro Con il Metodo GOPP; Franco Angeli: Milano, Italy, 2001.

10. Cattaneo Vietti, R.; Tunesi, L. Le aree marine protette in Italia; Problemi e prospettive: Aracne, Roma, 2007; Available online: http://www.aracneeditrice.it/pdf/9788854814363.pdf (accessed on 26 November 2019).

11. Cicin-Sain, B.; Belfiore, S. Linking marine protected areas to integrated coastal and ocean management: A review of theory and practice. Ocean Coast. Manag. 2005, 48, 847-868. [CrossRef]

12. Cicin-Sain, B.; Knecht, R.W.; Vallega, A.; Harakunarak, A. Education and training in integrated coastal management: Lessons from the international arena. Ocean Coast. Manag. 2000, 43, 291-330. [CrossRef]

13. Comitato per il Capitale Naturale, Secondo rapporto sullo stato del capitale naturale in Italia, 2018. Available online: https://www.minambiente.it/sites/default/files/archivio/allegati/sviluppo_sostenibile/II_Rapporto_ Stato_CN_2018_2.pdf (accessed on 29 November 2019).

14. Devuyst, D.; Hens, L.; De Lannoy, W. Chapter 5: Linking Impact Assessment with Sustainable Development and the Introduction of Strategic Environmental Assessment. In How Green Is the City? Columbia University Press: New York, NY, USA, 2001.

15. European Commission; DG XI Environment, Nuclear Safety and Civil Protection. A Handbook on Environmental Assessment of Regional Development Plans and EU Structural Funds Programmes; Environmental Resources Management: London, UK, 1998; Available online: http://ec.europa.eu/environment/archives/eia/seaguidelines/handbook.htm (accessed on 2 December 2019).

16. European Commission. Directive 2008/56/EC of the European Parliament and of the Council. Available online: https://eur-lex.europa.eu/legal-content/EN/TXT/PDF/?uri=CELEX:32008L0056\&from=EN (accessed on 10 November 2019).

17. European Commission. Report from the Commission to the European Parliament and the Council on the progress in establishing marine protected areas (as required by Article 21 of the Marine Strategy Framework Directive 2008/56/EC). Brussels, 1/10/2015. Available online: https://ec.europa.eu/transparency/regdoc/rep/1/ 2015/EN/1-2015-481-EN-F1-1.PDF (accessed on 25 September 2019).

18. European Environmental Agency. Marine Protected Areas. Available online: https://www.eea.europa.eu/ themes/water/europes-seas-and-coasts/assessments/marine-protected-areas (accessed on 25 September 2019).

19. European Environment Agency. Marine environment. Available online: https://www.eea.europa.eu/soer2015/europe/marine-and-coastal\#note21 (accessed on 25 September 2019).

20. European Union. 2012. Blue Growth. Opportunities for Marine and Maritime Sustainable Growth. Available online: https://ec.europa.eu/maritimeaffairs/sites/maritimeaffairs/files/docs/publications/blue-growth_en.pdf (accessed on 10 November 2019).

21. European Union. Directive 2014/89/Eu of the European Parliament and of the Council. Available online: https://eur-lex.europa.eu/legal-content/EN/TXT/PDF/?uri=CELEX:32014L0089\&from=EN (accessed on 10 November 2019).

22. Federparchi, Contabilità ambientale nelle Aree Marine Protette Italiane. Idea progettuale, 2014. Available online: http://www.torredelcerrano.it/wp-content/uploads/2016/11/2_Documento-Contabilit\% C3\%A0_ambientale_FEDERPARCHI-Roma-15-aprile-2014.pdf (accessed on 23 November 2019).

23. Fernandes, L.; Day, J.; Lewis, A.; Slegers, S.; Kerrigan, B.; Breen, D.; Cameron, D.; Jago, B.; Hall, J.; Lowe, D.; et al. Establishing representative no-take areas in the Great Barrier Reef: Large-scale implementation of theory on Marine Protected Areas. Conserv. Biol. 2005, 19, 1733-1744. [CrossRef] 
24. Fischer, T.B. Towards a more Systematic Approach to Policy, Plan and Programme Environmental Assessment-Some Evidence from Europe. In SEA in Australasia; Marsden, S., Dovers, S., Eds.; Sydney Place Federation Press: Sydney, Australia, 2002.

25. Gaston, K.J.; Pressey, R.L.; Margules, C.R. Persistence and vulnerability: Retaining biodiversity in the landscape and in protected areas. J. Biosci. 2002, 27, 361-384. [CrossRef] [PubMed]

26. GIREPAM, Gestione Integrata delle Reti Ecologiche attraverso i Parchi e le Aree Marine. Il progetto, n.d. Available online: http://interreg-maritime.eu/it/web/girepam/checosarealizza (accessed on 10 November 2019).

27. Gomes, I.; Pérez-Jorge, S.; Peteiro, L.; Andrade, J.; Bueno-Pardo, J.; Quintino, V.; Rodrigues, A.M.; Azevedo, M.; Vanreusel, A.; Queiroga, H.; et al. Marine biological value along the Portuguese continental shelf; insights into current conservation and management tools. Ecol. Indic. 2018, 93, 533-546. [CrossRef]

28. Groves, C.R. Drafting a Conservation Blueprint: A Practitioner's Guide to Planning for Biodiversity; Island Press: Washington, DC, USA, 2003.

29. Groom, M.J.; Vynne, C.H. Habitat Degradation and Loss. In Principles of Conservation Biology, 3rd ed.; Groom, M.J., Meffe, G.K., Carroll, C.R., Eds.; Sinauer Associates, Inc.: Sunderland, MA, USA, 2012; pp. 173-212.

30. Gurrutxaga San Vicente, M.; Lozano Valencia, P. La Integración de la Conectividad Ecológica en los Instrumentos de Ordenación y Planificación Territorial: Una Revision; Boletín de la A.G.E.: Madrid, Spain, 2019; n. 49; pp. 45-66.

31. Henson, S.A.; Beaulieu, C.; Ilyina, T.; John, J.G.; Long, M.; Seferian, R.; Tjiputra, J.; Sarmiento, J.L. Rapid emergence of climate change in environmental drivers of marine ecosystems. Nat. Commun. 2017, 8, 14682. [CrossRef]

32. Hilborn, R. The role of science in MPA establishment in California: A personal perspective. Environ. Conserv. 2012, 39, 195-198. [CrossRef]

33. Interreg. Il Programma Italia-Francia Marittimo. Available online: http://interreg-maritime.eu/it/programma (accessed on 10 November 2019).

34. IPBES (Intergovernmental Science-Policy Platform on Biodiversity and Ecosystem Services). The IPBES Regional Assessment Report on Biodiversity and Ecosystem Services for the Americas; Rice, J., Seixas, C.S., Zaccagnini, M.E., Bedoya-Gaitán, M., Valderrama, N., Eds.; IPBES: Bonn, Germany, 2018; 656p.

35. IPCC (Intergovernmental Panel on Climate Change). Climate Change 2001: The Scientific Basis. Contribution of Working Group I to the Third Assessment Report; Houghton, J.T., Ding, Y., Griggs, D.J., Noguer, M., Van der Linden, P.J., Dai, X., Maskell, K., Johnson, C.A., Eds.; Cambridge University Press: Cambridge, UK, 2003.

36. Italian Official Gazette. Regolamento di Esecuzione ed Organizzazione Dell'area Marina Protetta "Isola dell'Asinara. Available online: www.parcoasinara.org/it/contenuti/articoli/dettagli/553/ (accessed on 29 January 2020).

37. Jameson, S.C.; Tupper, M.H.; Ridley, J.M. The three screen doors: Can marine "protected" areas be effective? Mar. Pollut. Bull. 2002, 44, 1177-1183. [CrossRef]

38. Jentoft, S.; Chuenpagdee, R.; Pascual-Fernández, J.J. What are MPAs for: On goal formation and displacement. Ocean Coast. Manag. 2011, 54, 75-83. [CrossRef]

39. Jones, P.J. A review and analysis of the objectives of marine nature reserves. Ocean Coast. Manag. 1994, 24, 149-178. [CrossRef]

40. Kaiser, M.J. Are marine protected areas a red herring or fisheries panacea? Can. J. Fish. Aquat. Sci. 2005, 62, 1194-1199. [CrossRef]

41. Kajanus, M.; Leskinen, P.; Kurttila, M.; Kangas, J. Making use of MCDS methods in SWOT analysis—Lessons learnt in strategic natural resources management. For. Policy Econ. 2012, 20, 1-9. [CrossRef]

42. Kelleher, G. Guidelines for Marine Protected Areas; International Union for the Conservation of Nature: Gland, Switzerland, 1999.

43. Kørnøv, L.; Thissen, W. Rationality in Decision- and Policy-Making: Implications for Strategic Environmental Assessment. Impact Assess. Proj. Apprais. 2012, 18, 191-200. [CrossRef]

44. Leone, F.; Zoppi, C. Conflictual Issues Concerning Land Uses Related to Ecosystem Services under the Provisions of the Habitats and Birds Directives. Available online: http://www.input2016.it/conference_2016/ conference_proceedings (accessed on 29 January 2020). 
45. Linee Guida per la Valutazione ambientale strategica dei Piani urbanistici comunali [Guidelines Manual on Strategic Environmental Assessment of Municipal Masterplans], Annex to the Decision of the Regional Government of Sardinia n. 44/51 of 14 December 2010. Available online: http://www.sardegnaambiente.it/ documenti/18_269_20110203150553.pdf (accessed on 2 December 2019).

46. Lundquist, C.J.; Granek, E.F. Strategies for Successful Marine Conservation: Integrating Socioeconomic, Political, and Scientific Factors. Conserv. Boil. 2005, 19, 1771-1778. [CrossRef]

47. Margules, C.R.; Pressey, R.L. Systematic conservation planning. Nature 2000, 405, 243-253. [CrossRef]

48. Povero, P.; Vassallo, P.; Paoli, C.; Dapueto, G.; Massa, F.; Pozzi, M.; Armenio, M.; Rigo, I.; Congiatu, P.; Gazale, V.; et al. Contabilità Ambientale nelle Aree Marine Protette Italiane. Ecorendiconto dell'Isola dell'Asinara; Report finale; Parco Nazionale dell'Asinara, CoNISMa: Genova, Italy, 2018.

49. Marino, D. Le aree marine protette italiane. Stato, politiche, governance; Franco Angeli: Milano, Itlay, 2011.

50. ME (Millennium Ecosystem Assessment), Ecosystems and Human Well-being. A Framework to Assessment, Island Press, 2003. Available online: http://pdf.wri.org/ecosystems_human_wellbeing.pdf (accessed on 13 November 2019).

51. Ministero dell'Ambiente, della Tutela del Territorio e del Mare (MATTM). Studio e analisi delle forme di coesistenza e criticità tra sviluppo economico- sociale e conservazione della natura. Il ruolo dei processi partecipati. Verso la strategia nazionale per la biodiversità, 2018. Available online: https: //www.minambiente.it/sites/default/files/archivio/biblioteca/dpn_tavolo1_partecipazione.pdf (accessed on 29 November 2019).

52. Murray, S.N.; Ambrose, R.F.; Bohnsack, J.A.; Botsford, L.W.; Carr, M.H.; Davis, G.E.; Dayton, P.K.; Gotshall, D.; Gunderson, D.R.; Hixon, M.A.; et al. No-take Reserve Networks: Sustaining Fishery Populations and Marine Ecosystems. Fisheries 1999, 24, 11-25. [CrossRef]

53. Navarro Ortega, A. Las áreas marinas protegidas: ¿Un instrumento para la gestión eficiente del medio marino en España? In Proceedings of the III Congresso Internacional do Mar “A Proteção do Ambiente Costeiroe Marinho", Universidade Lusíada, Lisboa, Portugal, May 2014.

54. Nobre, A.M.; Ferreira, J.G. Integration of ecosystem-based tools to support coastal zone management. JCR 2009, SI 56, 1676-1680.

55. Norse, E.A. Global Marine Biological Diversity: A Strategy for Building Conservation into Decision Making; Island Press: Washington, DC, USA, 1993; pp. 3-9.

56. Paoli, C.; Povero, P.; Burgos, E.; Dapueto, G.; Fanciulli, G.; Massa, F.; Scarpellini, P.; Vassallo, P. Natural capital and environmental flows assessment in marine protected areas: The case study of Liguria region (NW Mediterranean Sea). Ecol. Model. 2018, 368, 121-135. [CrossRef]

57. Parco Asinara. Aspetti Storico-Geografici. Available online: http://www.parcoasinara.org/it/contenuti/ articoli/dettagli/544/ (accessed on 12 November 2019).

58. Parco Asinara. Contenuti. Available online: http://www.parcoasinara.org/it/contenuti/articoli/dettagli/512/ (accessed on 12 November 2019).

59. Parsons, T.R. Biological coastal communities: Productivity and impacts, in Coastal systems studies and sustainable development. UNESCO TPMS 1992, 64, 27-37.

60. Partidärio, M.R. Strategic environmental assessment: Key issues emerging from recent practice. Environ. Impact Assess. Rev. 1996, 16, 31-55. [CrossRef]

61. Potts, T.; Burdon, D.; Jackson, E.; Atkins, J.; Saunders, J.; Hastings, E.; Langmead, O. Do marine protected areas deliver flows of ecosystem services to support human welfare? Mar. Policy 2014, 44, 139-148. [CrossRef]

62. Rogers, A.; Sumaila, U.; Hussain, S.; Baulcomb, C. The High Seas and Us: Understanding the Value of High-Seas Ecosystems; Report 2014; Global Ocean Commission: Oxford, UK, 2014.

63. Sadler, B.; Verheem, R. Strategic Environmental Assessment-Status, Challenges and Future Directions; Ministry of Housing, Spatial Planning and the Environment: The Hague, The Netherlands, 1996.

64. Salm, R.V.; Clark, J.R. Marine and Coastal Protected Areas: A Guide for Planners and Managers; IUCN: Gland, Switzerland, 2000.

65. Scott, J.M.; Davis, F.W.; McGhie, R.G.; Wright, R.G.; Groves, C.; Estes, J. Nature reserves: Do they capture the full range of America's biological diversity? EA 2001, 11, 999-1007. [CrossRef]

66. Sheate, W.R.; Dagg, S.; Richardson, J.; Aschemann, R.; Palerm, J.; Steen, U. Integrating the environment into strategic decision-making: Conceptualizing policy SEA. Eur. Environ. 2003, 13, 1-18. [CrossRef] 
67. Smith, V.; Tilman, G.; Nekola, J. Eutrophication: Impacts of excess nutrient inputs on freshwater, marine, and terrestrial ecosystems. Environ. Pollut. 1999, 100, 179-196. [CrossRef]

68. Zoppi, C. Integration of Conservation Measures Concerning Natura 2000 Sites into Marine Protected Areas Regulations: A Study Related to Sardinia. Sustainability 2018, 10, 3460. [CrossRef] 